

\section{Sumário}

EDITORIAL

Bruno Amaral Machado, Camilla de Magalhães Gomes e Soraia Mendes

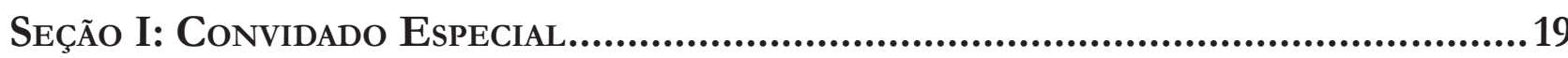

Autonomia Pessoal, Destino, julgamentos e instituições no Brasil: Notas Sobre uma PERGUNTA E ALGUMAS RESPOSTAS

Luiz Edson Fachin

SEÇÃo 2: Dossiê Temático....................................................................................40

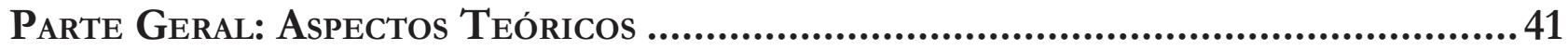

Raça e essencialismo na Teoria Feminista do Direito .......................................................43

Angela P. Harris, Tradução de Camilla de Magalhães Gomes e Ísis Aparecida Conceição

Políticas da morte: Covid-19 E Os Labirintos da Cidade Negra ........................................75

Ana Flauzina e Thula Pires

QUem PARIU AMÉFrica?: TRABALHO DOMÉSTICO, CONSTITUCIONALISMO E MEMÓRIA EM PRETUGUÊS

Juliana Araújo Lopes

O Lixo Vai Falar: Racismo, Sexismo e Invisibilidades do Sujeito Negro nas Narrativas de Direitos Humanos

Ciani Sueli das Neves

DiREITOS HUMANOS, DECOLONIALIDADE E FEMINISMO DECOLONIAL: FERRAMENTAS TEÓRICAS PARA A COMPREENSÃO DE RAÇA E GÊNERO NOS LOCAIS DE SUBALTERNIDADE

Rute Passos, Letícia Rocha Santos e Fran Espinoza

Direito, RAÇA E GÊNERO: ELEMENTOS PARA A CONSTRUÇÃo DE UMA TEORIA FEMINISTA DO DIREITO ADEQUADA AO FEMINISMO NEGRO

Mário Lúcio Garcez Calil e Debora Markman

"NeGras VAdiAs": A CRIMINALIZAÇÃo Do CORPO NEGRO QUE OUSA PROTESTAR.

Soraia da Rosa Mendes e Bruno Amaral Machado

A experiênCia do Abaetê Criolo como aÇão de enfrentamento a desigualdades de GÊNERO E RAÇA: UMA ANÁLISE DE DISCURSO SOBRE INTERSECCIONALIDADE

E FEMINISMO NEGRO

David Oliveira e Thalita Terto Costa 
ENTRE A AUSÊNCIA E O EXCESSO: A ATUAÇÃo DO ESTADO SOBRE CORPOS DISSIDENTES 230 Dayane do Carmo Barretos, Klelia Canabrava Aleixo e Vanessa de Sousa Soares

SILÊNCIOS E MITOS NUMA PERSPECTIVA INTERSECCIONAL: DO CONTROLE INFORMAL DE CORPOS AO CONTROLE PENAL DE MULHERES NEGRAS ......................................................248 Elaine Pimentel e Nathália Wanderley

Ministério Público e domínio Racial: poucas ilhas negras EM UM ARQuipélago nãoNEGRO 267

Saulo Murilo de Oliveira Mattos

Políticas públicas Para a ARTiCulaÇão de GÊNERo E RAÇA: MEIOS PARA GARANTir A REPRESENTATIVIDADE POLÍtiCA E JURÍDiCA DA MULHER NEGRA NO BRASIL 296 Mariana Dionísio de Andrade e Eduardo Régis Girão de Castro Pinto

Parte Específica: Incidências Concretas.......................................................... 317

REIMAGING THE POLICING OF GENDER VIOLENCE: LESSONS FROM WOMEN'S POLICE STATIONS IN Brasil AND ArgENTINA............................................................................................ 319 Kerry Carrington, Melissa Bull, Gisella Lopes Gomes Pinto Ferreira e María Victoria Puyol

NECROBIOPOLIÍtica DE GÊNERo No BRASIL CONTEMPORÂNEO: O FEMINICÍDIO EM TEMPOS DE FASCISMO SOCIAL 340 Maiquel Ângelo Dezordi Wermuth e Joice Graciele Nielsson

ViolÊNCIA CONTRA MULHERES QUILOMBOLAS: UMA REFLEXÃo SOBRE A APLICAÇÃo DE UMA PERSPECTIVA INTERSECCIONAL À LUZ DA IDEIA DE CONTRAPÚBLICOS SUBALTERNOS DELINEADA POR FRASER..... 360 Maria Eugenia Bunchaft, Leonardo Rabelo de Matos Silva e Gustavo Proença da Silva Mendonça

Políticas públicas de PREVEnÇÃo aO Feminicídio E INTERSECCIONALIDAdes . 384 Thiago Pierobom de Ávila, Marcela Novais Medeiros, Cátia Betânia Chagas, Elaine Novaes Vieira, Thais Quezado Soares Magalhães e Andrea Simoni de Zappa Passeto

DiREITO DE VIVER SEM VIOLÊNCIA: PROTEÇÃO E DESAFIOS DOS DIREITOS DAS MULHERES indígenas no Sistema InTERAmericano de Direitos Humanos Julia Natália Araújo Santos e Felipe Rodolfo de Carvalho

ANÁlise de GÊNERo E DE CRUZAMENTOS INTERSECCIONAIS DE UM PROGRAMA PARA AUTORES DE VIOLÊNCIA DOMÉSTICA CONTRA AS MULHERES

Mariana Fernandes Távora, Dália Costa, Camilla de Magalhães Gomes e Adriano Beiras

Controle PENAL dA LOUCURA E DO GÊNERO: REFLEXÕES INTERSECCIONAIS SOBRE MULHERES EgRESSAS DA MEdidA DE SEgurANÇA No Rio DE JANEIRO. .468 Bruna Martins Costa e Luciana Boiteux 
ONDE ESTÃo NOSSOS DIREITOS? O CAMPO FEMINISTA DE GÊNERO BORDADO PELAS MULHERES ATINGIDAS POR BARRAGENS

Tchenna Fernandes Maso e Tchella Fernandes Maso

Os SEGREDOS EPISTÊMICOS DO DIREITO DO TRABALHO.

Flávia Souza Máximo Pereira e Pedro Augusto Gravatá Nicoli

Reforma trabalhista e desigualdade de GÊNERo no Brasil: uMa PERSPECTIVA JuRÍdicA E ECONÔMICA

Natalia Branco Lopes Krawczun, Magno Rogério Gomes e Solange de Cassia Inforzato de Souza

A COLONIALIDADE DO PODER NA PERSPECTIVA DA INTERSECCIONALIDADE DE RAÇA E GÊNERO: ANÁLISE DO CASO DAS EMPREGADAS DOMÉSTICAS NO BRASIL .565

Daphne de Emílio Circunde Vieira Andrade e Maria Cecília Máximo Teodoro

COMPETIÇÃO POLÍTICA E DESIGUALDADES DE GÊNERO NAS ELEIÇÕES PARA ASSEMBLEIAS ESTADUAIS EM 2018

Lígia Fabris Campos, Décio Vieira da Rocha, Leandro Molhano Ribeiro e Vitor Peixoto

DisCrit: os LIMITES DA INTERSECCIONALIDADE PARA PENSAR SOBRE A PESSOA NEGRA COM DEFICIÊNCIA

Philippe Oliveira de Almeida e Luana Adriano Araújo

SeÇão III: Temais GeraIS

La Corte Interamericana de Derechos Humanos. Hermenéutica del derecho al MEDIO AMBIENTE SANO, A LA IDENTIDAD CULTURAL Y A LA CONSULTA, A LA LUZ DE LA SENTENCIA “Lhaka Honhat (nUestra tierra) vs. Argentina” (2020)

Juan Jorge Faundes Peñafiel, Cristobal Carmona Caldera e Pedro Pablo Silva Sánchez

LA RESPUESTA INSTITUCIONAL FRENTE A LA TRATA DE PERSONAS EN EL ESTADO DE CHIHUAHUA.

UN ANÁLISIS DE POLÍTICA PÚBLICA .676 Martha Aurelia Dena Ornelas

Comunidades quilombolas, RaCismo e ideologia no discurso de JAIr Bolsonaro: estudo CRÍTICO DOS DISCURSOS POLÍTICO E JUDICIAL 700 Ricardo de Macedo Menna Barreto e Helena Mascarenhas Ferraz

O Princípio Geral da Boa Administração no Código do Procedimento Administrativo Português. Pistas de inVestigação. 724 Ana Melro 


\title{
Ministério Público e domínio racial: poucas ilhas negras em um arquipélago não-negro*
}

\author{
Public Prosecutor and racial domain: few \\ black islands in a non-black archipelago
}

Saulo Murilo de Oliveira Mattos**

\section{Resumo}

O presente artigo tem como objetivo analisar o perfil racial do Ministério Público da Bahia, bem como identificar a dinâmica de acesso a espaços de poder, dentro da instituição, por promotores (as) negros (as). Verifica-se como o perfil racial da instituição pode interferir em seu compromisso com a defesa de direitos fundamentais. Adota-se como hipótese a ideia de que o Ministério Público baiano desenvolve suas atividades constitucionais baseadas na ilusão de uma democracia racial, que existiria tanto dentro como fora da instituição, o que o afasta das reais demandas sociais. Neste artigo, a análise multidisciplinar (dogmática, história e teoria crítica racial) se conecta com a perspectiva interseccional de raça e gênero (feminismo negro). São demarcadores teóricos os conceitos de racismo estrutural, antinegritude, quilombismo e amefricanidade. Com metodologia hipotética-dedutiva, de viés analítico, utilizou-se pesquisa bibliográfica, análise documental (discursos de posse e notícias de imprensa) e levantamento quantitativo de dados sobre raça e gênero no Ministério Público da Bahia, com destaque para órgãos de cúpula (Procuradoria-Geral e Corregedoria). Ao se analisar a concepção moderna de Ministério Público, situada, historicamente, no período da Revolução Francesa, de onde surge a abstração conceitual Estado de Direito, concluiu-se, por meio dos aludidos conceitos, que o Ministério Público da Bahia está imerso, institucional e socialmente, num ambiência antinegra, que enfraquece o exercício de suas atribuições constitucionais. A abordagem é original pela ausência de um estudo específico sobre o perfil racial do Ministério Público baiano, e que seja comprometido com uma análise qualitativamente marcada pela crítica racial.

Palavras-chave: Ministério Público; Perfil Racial; Antinegritude.

* Recebido em 30/05/2020 Aprovado em 16/09/2020

** Promotor de justiça do MP/BA, mestre em Segurança Pública, Justiça e Cidadania pela UFBA, mestrando em raciocínio probatório pela Universidade de Girona/ES, professor de processo penal convidado da pós-graduação lato sensu em Ciências Criminais da Universidade Católica de Salvador (Ucsal). Associado do Instituto Baiano de Direito Processual Penal (IBADPP). E-mail: mattossaulo@gmail.com

\section{Abstract}

This article aims to analyze the racial profile of the Public Ministry of Bahia, as well as to identify the dynamics of access to spaces of power, within the institution, by black prosecutors. It is verified how the racial profile of the institution can interfere in its commitment to the defense of fundamental rights. The hypothesis is that the Public Prosecutor's Office in Bahia develops its constitutional activities under the illusion of a racial democracy, which would exist both inside and outside the institution, which distances 
it from real social demands. In this article, multidisciplinary analysis (dogmatic, history and critical racial theory) connects with the intersectional perspective of race and gender (black feminism). Theoretical frameworks are the concepts of structural racism, anti-blackness, quilombism and amefricanity. With a hypothetical-deductive methodology, with an analytical bias, bibliographic research, document analysis (possession speeches and press news) and quantitative data collection on race and gender at the Public Prosecutor's Office of Bahia were used, with emphasis on dome bodies (Attorney General and Internal Affairs). When analyzing the modern conception of the Public Ministry, historically located in the period of the French Revolution, from where the conceptual abstraction Rule of Law arises, it was concluded, through the mentioned concepts, that the Public Prosecutor's Office in Bahia is immersed, institutionally and socially, in an anti-black environment, which weakens the exercise of its constitutional attributions. The approach is original due to the absence of a specific study on the racial profile of the Bahia Public Prosecutor's Office, which is committed to an analysis qualitatively marked by racial criticism.

Keywords: Public Prosecutor; Racial Profile; Anti-blackness.

\section{Introdução}

Defender e garantir direitos fundamentais é uma das composições vocabulares mais expressivas do texto constitucional. A Constituição de 1988 entrega essa ação de promoção da dignidade da pessoa especialmente ao Ministério Público (art. 127/CF), sem que com isso sejam anulados outros programas normativos direcionados às demais instituições, direta ou indiretamente, ligadas aos direitos humanos positivados no ordenamento jurídico.

Essa montagem discursiva constitucional, sinteticamente apresentada como promoção da dignidade humana, é também a base normativa e axiológica da democracia brasileira. A democracia deve existir para que todos (as) consigam ter, com preservação de seus direitos fundamentais, uma existência digna. É uma definição mínima e teleológica de democracia, e que se encontra bem estabilizada na doutrina ${ }^{1}$, embora, às vezes, com alguns adjetivos que criticam a solidez da democraticidade brasileira: tardia, incompleta ou em vias de concretização.

No âmbito jurídico, as discussões constitucionalistas, como regra, estão focadas em realizar um desfile de momentos históricos do cenário político brasileiro - democracia e hiatos ditatoriais ou, noutro formato,

\footnotetext{
Valendo-se de uma Teoria Política Purista, essa definição de democracia é adotada por José Afonso da Silva, um dos precursores da doutrina constitucional brasileira. Cf. SILVA, José Afonso da. Comentários contextual à Constituição. $2^{\mathrm{a}}$ ed. São Paulo: Malheiros, 2006. p.41. Seguindo essa linha purista, ao tratarem da complexidade social para a realização da democracia, Streck e Bolzan elencam a escola, o consumo, os afetos e as relações jurídicas e jurisdicionais como fatores que integram o conteúdo da democracia; todavia, nada registram sobre a questão racial brasileira. Cf. STRECK, Lenio Luiz; MORAIS, José Luís Bolzan de. Ciência política e teoria do estado. Porto Alegre: Livraria do Advogado, 2019. p. 134-136. No mesmo sentido, Ayres Britto, apesar de o tom poético para definir a democracia como um megaprincípio, se mostrou omisso sobre a importância de se debater a questão racial para a efetivação da democracia brasileira. Cf. BRITTTO, Carlos Ayres. Teoria da constituição. Rio de Janeiro: Forense, 2006. p. 183. Ao abordarem noções críticas sobre a participação social à luz de uma teoria democrática, Braulio Santos e José Magalhães não tratam da questão racial brasileira. Cf. MAGALHÃES, José Luiz Quadro; SANTOS, Braulio Magalhães. Notas para um debate principiológico sobre participação à lu₹ de uma teoria democrática. Rev. Bras. de Políticas Públicas, Brasília, v. 1, n. 2, p. 1-30, jul./dez. 2011. Em sentido diverso, o constitucionalista Daniel Sarmento, abordando criticamente, a partir da lupa étnico-racial, o princípio constitucional da igualdade como forma de implementação de uma democracia substancial, com considerações sobre discriminação de facto e teoria do impacto desproporcional. Cf. SARMENTO, Daniel. Livres e iguais: estudos de direito constitucional. Rio de Janeiro: Editora Lumen Juris, 2006. p. 143-147. Outra perspectiva interessante e que, de forma propositiva, sugere justificado desvio da tradição constitucional purista, é a leitura históricofuncional proposta por Bruno Barros e Rita Albrecht, que concebem a historicidade da população negra brasileira, carimbada pela discriminação racial, como terreno adequado para se sustentar a ideia de cidadania inclusiva, tão especial à noção de democracia escrita na Constituição. Cf. BARROS, Bruno Mello Correa; ALBRECHT, Rita Mara. A discriminação racial no Brasil e a ascensão do povo negro: um olhar a partir dos princípios constitucionais na luta pela cidadania inclusiva. Revista Brasileira de Políticas Públicas, v. 9, n. ${ }^{\circ}$ 1, p. 14-33, 2019. Ver, ainda, a brilhante dissertação de mestrado de Livia Vaz, intitulada Ações Afirmativas: aplicação às políticas de saúde para a população negra. UFBA-2006 - 222p. Disponível em https://repositorio.ufba.br/ri/handle/ri/9304. Acesso em: 10. ago. 2020.
} 
ditaduras e hiatos democráticos. Nesse desfile teórico de ideias, quase sempre os debates estão relacionados à maior ou menor amplitude de direitos fundamentais que foram positivados na Constituição. Pouco se diz, no entanto, quanto ao devir escravocrata que compõe a estruturação social e política do Brasil, e que, portanto, é base sociológica fundamental para se pensar em efetivas alternativas à implementação de direitos fundamentais.

Impossível falar sobre direitos fundamentais sem debater e pensar em estratégicas político-jurídicas que analisem a estrutura racista em que está imersa a sociedade brasileira e tende a se perpetuar no espaço intergeracional. Opera-se com vigor uma transmissão de sesmarias de privilégios sociais entre pessoas que integram um mesmo grupo étnico-racial: a branquitude e suas múltiplas personas que se refestelam entre si. Regogizam-se em detrimento de outro grupo, a negritude ${ }^{2}$, assim designada pela "marca de ferro quente" herdada durante o transcurso de uma contínua e multissecular opressão racial, que a exclui constantemente do acesso a uma vida digna, mais leve, menos traumática, não tão tentadora ao suicídio, esquiva da ação destrutiva em massa politicamente determinada pelo racismo estrutural.

Conforme enfatiza Silvio Almeida, o racismo estrutural deve ser lido com base na Teoria Social, de maneira que não é um tipo específico de racismo, pois racismo é sempre estrutural enquanto elemento que organiza a sociedade em relações econômicas, políticas e de formação de subjetividades, formatando práticas institucionais, sociais e estilos de pensar que têm como base a superioridade étnico-racial. ${ }^{3}$

Como a doutrina e dogmáticas constitucionais oferecem ferramentas conceituais que são manejadas pelas instituições estatais, principalmente as do sistema de justiça, tem-se, como primeira reflexão, o fato de que as instituições de justiça desempenham suas atividades, a partir de um conceito abstrato, quase ficcional, de democracia. Conceito que, distante das relações raciais assimétricas que caracterizam a sociedade brasileira, se torna incapacitante de vidas. No Brasil, em especial no ciclo das elites medianas, o racismo é tratado como assunto superado: ou nunca existiu ou foi resolvido pelo processo de miscigenação brasileira, configuradora da fantasiosa democracia racial.

Essa é uma interpretação que pode ser extraída da ausência de discussão, em livros e congressos jurídicos, sobre a questão racial brasileira. A temática racial tem sido debatida, como regra, apenas sobre aspectos relacionados a cotas ${ }^{4}$ e o exercício de direito de propriedade referente as algumas comunidades quilombolas remanescentes 5 . Ainda assim, a temática é enquadrada como uma conquista jurídica e ideológica de movimentos negros, e não como a grande discussão a ser travada para a implementação da Constituição. Não poderia ser diferente. Os escritores daqueles livros e os palestrantes daqueles congressos costumam integrar o grupo social que entre si exerce o cúmplice silêncio que assegura os típicos privilégios da branquitude.

Como consequência, toda instituição jurídica que se vale, inadvertidamente, dessa concepção artificial de democracia, que entende como realizada a democracia racial, multiplica, nas práticas do universo jurídico, essa artificialidade conceitual que abrevia direitos e cancela projetos de vidas, para os quais se mortificam

\footnotetext{
2 Ao abordar as significações que podem ser atribuídas à negritude, que poderia ser uma palavra constantemente designada no plural, Kabengele Munanga indica a existência de fatores históricos, linguísticos e psicológicos que interagem entre si na definição de negritude. Considera que "a negritude e/ou a identidade negra se referem à história comum que liga de uma maneira ou de outra todos os grupos humanos que o olhar do mundo ocidental 'branco' reuniu sob o nome de negros. A negritude não se refere somente à cultura dos povos portadores da pele negra, que de fato são todos culturalmente diferentes. Na realidade, o que esses grupos humanos têm fundamentalmente em comum não é como parece indicar, o termo Negritude à pele, mas sim o fato de terem sido, na história, vítimas das piores tentativas de desumanização e de terem sido suas culturas não apenas objeto de políticas sistemáticas de destruição, mas, mais do que isso, de ter sido simplesmente negada a existência dessas culturas." Cf. MUNANGA, Kabengele. Negritude-usos e sentidos. $4^{\text {a }}$ ed. Belo Horizonte: Autêntica, 2019. p. 19.

3 Cf. ALMEIDA, Silvio. Racismo estrutural. São Paulo: Polén, 2019. p. 20 -21.

4 Uma abordagem interessante sobre o tema, com referências a teorias da justiça, se encontra em MINHOTO, Antonio Celso Baeta. Refletindo sobre liberdade e igualdade dos negros: as ideias de Rawls e Walzer para um debate da ação afirmativa. Revista Brasileira de Políticas Públicas, v. 3, n. ${ }^{\circ}$, p.105-117, 2013.

5 Neste sentido, denunciando o descaso estatal e social à compreensão dos modos de existir das comunidades quilombolas, vale a pena conferir: MAGNAVITA, Andréa Costa. Invisibilidade pública: a bistória quilombola. Padê: Estudos em filosofia, raça, gênero e direitos humanos, v. 1, n. $^{\circ}$ 1, p. $17-33$, jan./jun. 2010
} 
dois objetivos fundamentais da República Federativa do Brasil: construir uma sociedade justa, livre, solidária e promover o bem de todos, sem preconceitos de origem, raça, sexo, cor, idade e quaisquer outras formas de discriminação. ${ }^{6}$

Ainda assim, mesmo ao se afirmar, inicialmente, a existência de um racismo estruturante da sociedade brasileira, deve-se pensar em outra chave analítica, que avança para uma compreensão mais crua e próxima da realidade brasileira. Fala-se da antinegritude ${ }^{7}$. Por essa visão, "a antinegritude torna abjeto tudo o que é supostamente ligado à negritude. A antinegritude torna não lugares todos os espaços marcados pela negritude: espaços físicos, espaços metafísicos, espaços ontológicos, espaços sociais."»

No Brasil, a questão racial não é só uma pauta que evidencia a segregação de grupos étnicos diferentes. É uma segregação que, na raiz das existências intersubjetivas, destrói, sistematicamente, vidas negras, a todo tempo. A cada dia, novas notícias da mídia sobre a morte de jovens e crianças negras moradoras das comunidades. Como diz João Costa Vargas, "a morte negra não causa escândalo."”

E essa marca não escandalizante, não espantosa, da morte negra é exemplo diário da antinegritude brasileira.

Pela lupa da antinegritude, verifica-se a descartabilidade da negritude, de modo que pessoas negras "constituem o não ser que fundamenta as subjetividades não negras do mundo moderno ${ }^{10 ”}$. Mostrar-se-á como essa lógica pode ser levada para uma nova leitura sobre as relações institucionais e sociais do Ministério Público.

Não há e nunca houve democracia racial no Brasil, situação que já foi denunciada por intelectuais negros (as) há muito tempo, como Abdias Nascimento que, na década de setenta, em nenhum momento recuou em seu pensamento para afirmar, com dados empíricos, no plano nacional e internacional, nas Conferências Mundiais de Artes e Culturas Negras, que a democracia racial e o discurso da metarraça brasileira são mecanismos usados para a continuidade branca no poder. Com isso, Abdias Nascimento não somente denunciava o processo de um racismo mascarado, apontava sobretudo para o fato de que esse racismo mascarado tem provocado o extermínio sistemático da negritude, ao que se pode chamar de genocídio do negro brasileiro. ${ }^{11}$

A intelectual Lélia Gonzalez não deixou de registrar que, a respeito dessa democracia racial, a população negra somente deteriora suas condições materiais e psicológicas, justamente o que aconteceu na década de

\footnotetext{
Em recente artigo, a constitucionalista Ana Paula Barcellos, ao apontar a desconexão do constitucionalismo brasileiro em relação às novas ideologias constitucionais surgidas na América Latina, que abraçam o pluralismo jurídico, diz que o Judiciário brasileiro combina supremacia constitucional com o monismo jurídico, e continua a valorizar uma concepção estadocêntrica como base regulativa da ordem jurídica. A referida autora, buscando desenhar um novo cenário para o constitucionalismo brasileiro, apesar de reconhecer as normatividades de origem indígena, passa ao largo da questão racial. C.f. BARCELLOS, Ana Paula Gonçalves Pereira de. Constituição e pluralismo jurídico: a posição particular do Brasil no contexto latino-americano. Revista Brasileira de Políticas Públicas, v. 9, n. 2, p. 170-183, 2019.

A antinegritude, enquanto marco teórico, radicaliza a discussão racial, no sentido de colocar a condição de não-ser da pessoa negra como fundamento ontológico da própria Modernidade. Nesse sentido, pode ser vista como uma superação da proposição teórica trazida pelo racismo estrutural, e apresenta novo paradigma teórico, embora não negue a importância da concepção teórica do racismo. Por isso, o uso conceitual da noção de antinegritude é feita, no presente artigo, em uma perspectiva dinâmica, como um passo além da ideia de racismo estrutural, um estágio trágico da questão racial. Todavia, o autor João H. Costa Vargas não adota essa linha de raciocínio, no sentido de que, para se identificar a antinegritude, primeiramente há de se verificar o racismo estrutural. A própria antinegritude, pela ontologia que traz em sua formulação teórica, arrasta consigo o antagonismo estrutural, com nova díade classificatória: negros/não-negros. Pela ótica racista, diferentemente, o mundo social está dividido em pessoas brancas e pessoas não-brancas. VARGAS, João H. Costa. Racismo não dá conta: antinegritude, a dinâmica ontológica e social definidora da modernidade. Revista Em Pauta: teoria social e realidade contemporânea, v. 18, n. ${ }^{\circ}$ 45, p. 16-25, 2020.

8 VARGAS, João H. Costa. Racismo não dá conta: antinegritude, a dinâmica ontológica e social definidora da modernidade. Revista Em Pauta: teoria social e realidade contemporânea, v. 18, n. ${ }^{\circ}$ 45, p. 16-25, 2020.

9 VARGAS, João Costa. Por uma Mudança de Paradigma: Antinegritude e Antagonismo Estrutural. Revista de Ciências Sociais. Fortaleza, v.48, n. ${ }^{\circ} 2$, p.83-105, jul./dez., 2017.

10 VARGAS, João H. Costa. Racismo não dá conta: antinegritude, a dinâmica ontológica e social definidora da modernidade. Revista Em Pauta: teoria social e realidade contemporânea, v. 18, n. 45, p. 16-25, 2020.

11 NASCIMENTO, Abdias. O genocídio do negro brasileiro: processo de um racismo mascarado. $3^{\text {a }}$ ed. São Paulo: Perspectiva, 2016 . p.54. Para uma visão do genocídio da população negra e o caráter rudimentar do direito internacional em relação a essa questão: FLAUZINA, Ana Luiza Pinheiro. As fronteiras raciais do genocídio. University of Brasília Law Journal (Direito. UnB), v. 1, n. 1, p. 705, 2016.
} 
64 com o golpe militar, utilizando-se o negro como mão de obra baratíssima, perseguido pela polícia, tendo que mostrar uma carteira profissional como indício de algum grau de cidadania. ${ }^{12}$

Lelia Gonzalez diz também como a afirmação da igualdade jurídica é puramente formalista, diante de uma realidade social latino-americana, que apresenta um racismo sofisticado para deixar negros e índios em cativeiros sociais, sendo explorados, ao máximo, na dinâmica do capitalismo e absorvidos pela ideologia do branqueamento. Com razão, Lelia Gonzalez convoca a uma retomada consciente de um fato histórico - a presença da "África” na América-Latina — para que, então, a negritude estabeleça um cotidiano afrocentrado. A referida pensadora estabelece a categoria político-cultural da Amefricanidade, a qual, ao lado dos conceitos de racismo estrutural e antinegritude, integra o conjunto de demarcadores teóricos do presente $\operatorname{artigo.~}^{13}$

Feita essa contextualização, para exemplificar a importância de o Ministério Público ser compreendido com base no enfoque das relações raciais no Brasil, escolheu-se o Ministério Público baiano como espaço institucional de análise, já que está situado em um Estado, cuja população é predominantemente negra, com percentual de $80 \%$ de pretos e pardos, conforme últimos dados apresentados pelo IBGE. ${ }^{14}$

Nesse sentido, a hipótese trabalhada neste artigo se refere à ideia de que o Ministério Público baiano desenvolve suas atividades constitucionais, baseado na ilusão de uma democracia racial, que existiria tanto dentro como fora da instituição, o que acaba por afastá-lo das reais demandas sociais. A partir dessa hipótese, tenta-se identificar o perfil racial do Ministério Público baiano e pensar se esse perfil racial é uma variável importante a ser considerada para a efetividade das atribuições constitucionais.

Analisa-se a dinâmica da antinegritude institucional, quando se verifica, por meio de retrospectiva histórica do fluxo de carreiras da instituição, a real possibilidade de promotores (as) negros (as) assumirem posicionalidades de liderança institucional, e qual o reflexo disso na própria concepção de Ministério Público.

Como substrato histórico, desenvolveu-se raciocínio crítico quanto à Revolução Francesa (1789), que, apenas com a proclamação de ideais de liberdade, igualdade e fraternidade, não conseguiu garantir a formação de um Estado de Direito, que se afastasse da opressão aos mais vulneráreis. Contrapõe-se a Revolução Francesa à Revolução do Haiti (1791-1804), cujos efeitos positivos se mostraram assustadores à França. Realiza-se uma crítica racial à Revolução Francesa, indicando-se como, de fato, ela não foi pensada para todos.

Essa crítica, que se libera de uma visão linear do fluxo histórico da humanidade, se revela importante, na medida em que o Ministério Público brasileiro guarda suas raízes modernas nessa época dita como proclamadora de direitos universais. A luminosidade constitucional do Ministério Público tem como base histórica as concepções iluministas do século XVIII. A não linearidade histórica mostra como o século das luzes não proporcionou uma iluminação tão potente para os novos fatos históricos que lhe seguiram.

Escolhida a metodologia hipotética-dedutiva, de viés analítico, foram analisados dados quantitativos referentes à composição racial do Ministério Público da Bahia, desde o quadro geral de promotores de justiça até a Administração Superior, considerada, ainda, a variável gênero. As informações foram solicitadas, por e-mail, à Secretaria-Geral do Ministério Público, que conseguiu, por meio do Sistema Integrado de Gestação de Informação (SIGA), passar um panorama quantitativo sobre a composição racial da instituição.

Todavia, nem todas as solicitações foram atendidas, diante da natural dificuldade de compilar, em pouco tempo, dados que envolvem uma instituição organicamente complexa. Por isso, neste artigo, apresentam-se

\footnotetext{
12 GONZALEZ, Lélia. O golpe de 64, o novo modelo econômico e a população negra. In: GONZALEZ, Lélia; HASENBALG, Carlos Alfredo. Lugar de negro. Rio de Janeiro: Marco Zero, 1982. p. 11-18.

13 GONZALEZ, Lelia. A categoria política-cultural de amefricanidade. In: Tempo Brasileiro. N. 92/93 (jan./jun). Rio de Janeiro: Tempo Brasileiro, 1988 p. 69-82.

14 Informações disponíveis em https://cidades.ibge.gov.br/brasil/ba/pesquisa/10070/64506.
} 
os primeiros dados obtidos sobre o perfil racial do Ministério Público baiano, cuja complexidade se intensifica quando se pensa no cruzamento desses dados nos diversos espaços de poder da instituição.

Algumas situações históricas, peculiares à questão racial no Ministério Público da Bahia, serão mencionadas como forma de proporcionar, de maneira mais detalhada, uma compreensão qualitativa desses primeiros dados

Antes de se abordar especificamente a estrutura racial do Ministério Público, far-se-á um rápido bosquejo histórico dessa ideia de vocação libertária denominada de Ministério Público.

\section{Ideia de Ministério Público: dilemas de uma historicidade liberal}

A determinação histórica do surgimento do Ministério Público pode ser atribuída a uma origem remota, vinculada à civilização egípcia e Antiguidade Clássica, com agentes públicos chamados, respectivamente, de Magiaí (Egito), Temóstetas (Grécia Antiga) e Praetor Fiscalis (Roma Antiga), que exerciam funções públicas relacionáveis a atividades que hoje são desenvolvidas pelo Ministério Público: formalização de acusações penais e tutela de pessoas incapazes para o exercício de seus direitos.

Pode ser referida a uma origem próxima, quando o Ministério Público passa a ser organizado como carreira de Estado no século XIII na França, reunindo em uma só instituição, o exercício daquelas funções antes exercidas de forma pulverizada na Antiguidade, além de outras que foram acrescentadas conforme as necessidades políticas do momento de sua densificação institucional.

Há, também, e de extrema relevância para a compreensão da feição moderna do Ministério Público, o momento histórico em que esse modelo estruturado de Ministério Público, corporificado mais ainda com o Code d'Instruction Criminelle de 1808, regido pela imposição política do autoproclamado imperador Napoleão Bonaparte, passa a ser expandido para a Europa como decorrência das invasões napoleônicas. ${ }^{15}$

Em relação a essa breve noção histórica, a ideia de Ministério Público, que foi disseminada para o mundo - Europa e respectivas colônias recém-libertas —, ocorre após o marco político que redimensionou a visão de Estado na Europa — a Revolução Francesa de 1789 —, que, com o tema liberdade, igualdade e fraternidade, conseguiu que esse bloco de ideias liberais fosse utilizado num modelo de Estado de Direito, que, nos próximos anos, seria amplamente implantado na Europa.

A ideia de Ministério Público que prevaleceu no mundo está atrelada a uma propulsão ideológica burguesamente revolucionária e liberal, que se satisfez, enquanto garantia de estabilidade política de uma nova dimensão da teleologia estatal (Estado de Direito), em assegurar formalmente liberdades públicas antes ignoradas pelo Antigo Regime. A juridicização formal dos princípios da igualdade, liberdade e a lógica de separação de poderes no trato da coisa pública encontraram respaldo e pretensão universalizante na Declaração dos Direitos do Homem e do Cidadão de 1789. Do século XVIII em diante, haverá a burocratização administrativa do Estado para suportar, com o desenvolvimento de carreiras estatais e funções públicas, os desejos liberais do Estado de Direito.

Contudo, essa linearidade histórica que aponta para uma transição gloriosa do Antigo Regime, denunciado como atroz, para o luminoso Estado de Direito é contestada por estudiosos do direito público. Gustavo Binenbojm considera essa linearidade histórica como uma ilusão garantística e mal compreendida do surgimento do Estado de Direito. O referido autor registra que o aparecimento do Estado de Direito se dá

\footnotetext{
5 Sobre as discussões referentes à origem histórica do Ministério Público: MAZZILLI, Hugo Nigro. Introdução ao ministério público. São Paulo: Saraiva, 2005. p. 35-38; GOULART, Marcelo Pedroso. Elementos para uma teoria geral do Ministério Público. Belo Horizonte: Arraes Editores, 2013. p. 69-74; LIMA, Polastri Marcellus. Ministério Público e Persecução Penal. $5^{a}$ ed. Salvador: Juspodivm, 2016. p. 26-35. ZANETI JR, Hermes. O Ministério Público e o novo processo civil. Salvador: JusPodivm, 2018, p. 15-38.
} 
de forma paradoxal, pois as categorias jurídicas nomeadas de legalidade, supremacia do interesse público, prerrogativas da Administração e separação de poderes representam antes "uma forma de reprodução e sobrevivência das práticas administrativas do Antigo Regime que sua superação". ${ }^{16}$

Gustavo Binenbojm sustenta essa conclusão na referência histórica de que o Direito Administrativo, na França pós-revolucionária, ao contrário do que se costuma acreditar doutrinariamente, não surgiu da submissão do Estado à vontade heterônoma do legislador, mas da própria autorregulação do Executivo francês, marcada por uma postura de insubmissão ao Parlamento. Por essa razão, desenvolveu-se, com força, o modelo de Contencioso Administrativo francês, em que a Administração julgaria a si própria, o que revela boa dose de desconfiança do Executivo em relação aos tribunais judiciais, um dos três Poderes. ${ }^{17}$

As inconsistências do liberalismo político francês também foram verificadas quanto à extensão do próprio conceito de liberdade. Domenico Losurdo relata que, no contexto do intelectualismo liberal francês, encontra-se em Montesquieu, na sua clássica obra Espírito das Leis (1748), definições que apontam para uma repulsa seletiva à escravidão, que deveria ser abolida na Europa, mas que poderia ser mantida, com uma menor carga opressiva no entanto, nos povos colonizados do sul do mundo, cujo clima quente favoreceria à permissão da escravidão, para que se explorasse um povo naturalmente debilitado por esse clima. Haveria, então, liberdade, igualdade e fraternidade plenas para uns, nem tanto para outros. ${ }^{18}$

Outra significativa reflexão sobre os paradoxos da Revolução Francesa e a escravidão refere-se a Susan Buck-Morss, que articula fundamentos históricos no sentido de que os ideais revolucionários franceses eram retóricos e selecionados para uma determinada expressão de poder social, que, na prática, pouco se preocupava com a continuidade da escravidão, inclusive em relação às próprias colônias francesas. A prova real da inconsistência filosófica-prática da Revolução Francesa se verificou com a Revolução Haitiana de 1791, que se dá, na colônia francesa de Saint-Domingue, com meio milhão de escravos, organizados e armados, que conquistaram a liberdade, transformando-se em movimento revolucionário que inspiraria revoluções em outras colônias francesas, abrindo os olhos do mundo para uma liberdade real. ${ }^{19}$

Se é possível apontar uma gênese política do Ministério Público Brasileiro, também conhecido pela expressão francesa Parquet $t^{20}$, é no contexto político acima descrito que começam a ser idealizadas que o faz ter atividades institucionais destinadas a garantir liberdade e igualdade para todos.

Como para todos, se são 132 anos de abolição inconclusa, com contínuo abafamento sangrento de vozes negras? ${ }^{21}$

16 BINENBOJM, Gustavo. Uma teoria do direito administrativo: direitos fundamentais, democracia e constitucionalização. $3^{\mathrm{a}}$ ed. Rio de Janeiro: Renovar, 2014, p. 11.

17 BINENBOJM, Gustavo. Uma teoria do direito administrativo: direitos fundamentais, democracia e constitucionalização. Rio de Janeiro: Renovar, 2014, p. 13-14.

18 LOSURDO, Domenico. Contra-história do liberalismo. Trad. Giovanni Semeraro. São Paulo: Ideias e Letras, 2020. p. 63 - 67.

19 BUCK-MORSS, Susan. Hegel e Haiti. Novos estudos. - CEBRAP, São Paulo n. 90, p. 131-171, jul. 2011.Disponível em <http://www.scielo.br/scielo.php?script=sci_arttext\&pid=S0101- 3002011000200010\&lng=pt\&nrm=iso >. Acesso em: 15 mai. 2020. https://doi.org/10.1590/S0101-33002011000200010. Outra visão interessantíssima é a desenvolvida por Evandro Piza e Marcos Queiroz, que, além de contrapor a Revolução Hatiana a essa historicidade linear que considera a revolução francesa como ponto crucial das novas civilizações ocidentais, sugere novo olhar sobre o tradicional historicismo constitucional, a partir da categoria Atlântico Negro, desenvolvida no livro homônimo, do britânico Paul Gilroy. A proposta é conceber o Constitucionalismo e a própria Modernidade sob as heterogeneidades de concepções e narrativas das diásporas africanas. Cf. DUARTE, Evandro Charles Piza; QUEIROZ, Marcos Vinícius Lustosa. A Revolução Haitiana e o Atlântico Negro: o Constitucionalismo em face do Lado Oculto da Modernidade. Revista Direito, Estado e Sociedade, n. ${ }^{\circ}$ 49, p. 10-42. jul/dez.2016.

20 De acordo com Fernando da Costa Tourinho Filho, "na França antiga os Procuradores e Advogados do Rei não se sentavam sobre o mesmo estrado onde ficavam os Juízes, mas sobre o soalho (parquet) da sala das audiências, como as partes e seus representantes. Hoje, não obstante os membros do Ministério Público fiquem no mesmo plano, a denominação "Parquet" é empregada para se referir à Instituição do Ministério Público.” C.f.TOURINHO FILHO, Fernando da Costa. Manual de processo penal. São Paulo: Saraiva, 2012.p.396.

21 Ao lado do caráter específico da escravização brasileira, trucidante de corpos negros, a sociabilidade institucional brasileira, conforme mostra Daina Tello, se encontra imersa em cultura latino-americana que não tem por hábito reconhecer os próprios erros, seja por medo de receber alguma censura pública ou perder a autoridade, o que impede o nascer de uma política estatal marcada pelo 
Florestan Fernandes, ao analisar sociologicamente o início da "livre" participação do negro no mundo dos brancos, registra que as ideias de economia de mercado, trabalho livre e modernização institucional não foram, na prática, tão promissoras quanto pareciam ser. Negros, rotulados de pessoas de cor, continuaram, no pós-abolição, submetidos a uma categorização sociorracial que autorizava a exploração desmedida de sua força de trabalho pelo segmento branco da sociedade. A inserção do negro no mundo branco foi regida por esse formato de relação racial assimétrica, continuando-se a lógica escravocrata ${ }^{22}$.

No mesmo sentido, com enfoque na relação colonizador/colonizado, Albert Memmi retrata que, assim como a burguesia necessita da imagem caricatural do proletariado, o colonizador "demanda e impõe uma imagem do colonizado". Em síntese, são imagens de tempos históricos diferentes, que se confundem, no entanto, na temática opressora. São imagens criadas pelos que se acham na condição de verticalizar a ação do poder e atribuir imagens a outro, desde que estas justifiquem a atitude exploratória do colonizador/ burguês ${ }^{23}$.

Feito esse parêntesis, não por acaso, conforme ficou indicado no cenário político de sua gênese, o Ministério Público brasileiro se constitui — não é uma contingência ou evento histórico acessório — do mesmo paradoxo das revoluções liberais do século XVIII. Embora, normativamente, seja um garantidor primaz das humanidades possíveis, sua cegueira deliberada em relação à força socialmente estruturante do fato histórico escravidão acaba por enfraquecer, substancialmente, seu potencial constitucional. Continua a negar os gritos de horror decorrentes das purulentas feridas sociais deixadas pela escravidão, duvidosamente cicatrizáveis. Afrodescendentes, maior parte da população brasileira, tropeçam sobre si sem acesso ao mínimo existencial. E o Ministério Público? O que fez, o que faz e o que fará?

A primeira mudança a se pensar é a reestruturação étnico-racial do Ministério Público brasileiro, impulsionada pelo despertar, multiplicar e agir de uma consciência negra sobre a negritude ${ }^{24}$ e uma consciência da branquitude referente aos privilégios sociais que sempre desfrutaram até ingressarem na instituição, e que se intensificam com o poder conferido e exercido na condição de promotor (a) de justiça. Sem isso, não é possível conceber ações institucionais multiplicadoras de direitos e garantias fundamentais. A dignidade de pessoa humana continua sendo, apenas, a de alguns, as dos sorteados pela ação institucional.

Discutir a branquitude é fomentar a aproximação de pessoas brancas que, conscientes de suas benesses sociais decorrentes de sua condição racial, se colocam, desde já e sempre, à disposição de um processo antirracista de transformação social. Aposta-se no conceito diferenciador proposto por Lourenço Cardoso, que indica como branquitude crítica justamente esta a que se referiu linhas atrás e branquitude acrítica aquela que ou se manifesta em movimentos de ultradireita radical, defensores da supremacia branca, ou silenciam, para não perderem seus privilégios sociais, sobre práticas estatais e individuais que excluem o acesso da população negra a melhores condições de (sobre)vida. ${ }^{25}$

\section{Ministério Público brasileiro: o peso constitucional de 1988}

autocontrole. C.f. TELLO, Diana Carolina Valencia. As instituições e a via da dependência histórica. Rev. Bras. de Políticas Públicas, Brasília, v. 1, n. ${ }^{\circ}$ 1, p. 35-64, jan./jun. 2011

22 FERNANDES, Florestan. O negro no mundo dos brancos. Global Editora e Distribuidora Ltda, 2015, p. 63.

23 MEMMI, Albert. Retrato do colonizado: precedido do retrato do colonizador. Trad. Marcelo Jacques de Moraes. Rio de Janeiro: Civilização Brasileira, 2007, p. 117.

${ }^{24}$ Essa proposta de consciência negra sobre o negro pode ser encontrada em Achille Mbembe, quando, ao atribuir um segundo significado para o termo razão negra, informa que esta seria a compreensão do negros sobre seu lugar no mundo, do caráter transfronteiriço das relações raciais, da diáspora africana e um sentimento de solidariedade marcado pelas históricas lutas abolicionistas e de contrariedade ao capitalismo. Cf. MBEMBE, Achille. Crítica da razão negra. Trad. Sebastião Nascimento. São Paulo: N-1 edições, 2018. p.63.

25 CARDOSO, Lourenço. A branquitude acrítica revisitada e as críticas. In: MÜLLER, Tânia MP; CARDOSO, Lourenço. Branquitude: estudos sobre a identidade branca no Brasil. Edição Kindle. Curitiba: Appris ,2017. p. 696-1127. 
É com a Constituição de 1988 que acontece, na história do Ministério Público, a grande viragem jurídica que o coloca como umas das instituições mais importantes do sistema de justiça. Instituição permanente e essencial à função jurisdicional do Estado, com possibilidade de elaborar a própria proposta orçamentária, terá à sua disposição um rol exemplificativo de funções institucionais, algumas anteriormente previstas em legislação esparsa, que substancializarão a missão constitucional central de defender a ordem jurídica, bem como direitos coletivos e difusos. Normativamente, é assim que se pode conhecer a instituição na leitura do art. 127 e ss. da CF/88.

Consolida-se, para o Ministério Público, imenso poder de agenda, de demanda, com a legitimidade constitucional para a propositura de ação penal e de ação civil pública para a realização de direitos transindividuais. Tudo isso o faz ser identificado, no campo da esperança social, principalmente a dos mais vulneráveis, como a voz da justiça social, do combate irrefreável em relação à impunidade, de tutor de uma sociedade que, ao escapar de 20 anos de ditadura, não mais suportaria ser negada no seu mínimo existencial.

Direitos e garantias fundamentais teriam vida real e seriam protegidos por mãos fiscalizadoras de uma instituição juridicamente revigorada. A dupla função do Ministério Público estava ali posta na Constituição de 1988: propor ações processuais relevantes e fiscalizar a ordem jurídica (custos constituciones).

No entanto, a Ciência Política estava atenta a esse processo de transformação institucional. É, com as pesquisas de Rogério Bastos Arantes, ${ }^{26}$ que se constata que essa transformação institucional do Ministério Público foi capitaneada por uns poucos que compunham a elite social e institucional de 1988, que não suportariam ver o Ministério Público novamente vinculado ao Poder Executivo, e que, com o discurso universalizante sobre direitos e garantias humanas, conseguiu, a custos de lobbies, fazer com que a calorosa Constituinte de 1988 fosse generosa com o Ministério Público.

À semelhança da Revolução Francesa, nascia um novo Ministério Público de 1988, coordenado politicamente por uma elite burguesa desejosa de maior estabilização político-institucional e que, com a suavidade do discurso de garantia de direitos fundamentais para todos na nova ordem democrática, conseguiu realizar seu, e só seu, projeto de constitucionalização orgânica do Ministério Público.

Superadas as festividades institucionais do pós-88, o que até então significava expressão de poder se transformou, no decorrer dos anos, em verdadeiro peso sobre os ombros do Ministério Público, que, com uma carreira de estado vitalícia e independente, não conseguia concretizar, a contento, todas as funcionalidades constitucionais.

Apesar de ter realizado importantes ações no campo da improbidade administrativa, criminal e saúde pública, a crítica, mais uma vez conduzida pela Ciência Política ${ }^{27}$, acompanhada agora por alguns juristas, constatou que a instituição não desenvolvia, satisfatoriamente, todas as funções institucionais que lhes foram previstas. Os membros da instituição tinham à sua disposição, para que não sofressem interferências políticas externas, garantias como a independência funcional, a inamovibilidade e a vitaliciedade. Constatou-se descompensação entre a potência das garantias institucionais e o desempenho de funções institucionais, também potentes, que, por razões outras, estavam sendo subaproveitadas.

Com tão poucos anos de vivência institucional após 1988, passou-se a falar em uma crise paradigmática do Ministério Público, questionando-se sua legitimidade social, que não decorria automaticamente de sua normatividade constitucional. Esta, a normatividade, concedida pelo Poder Constituinte, aquela, a legitimidade social, diariamente a ser construída com registros em um inventário próprio de acertos e erros institu-

26 ARANTES, Rogério Bastos. Direito e política: o Ministério Público e a defesa dos direitos coletivos. Revista brasileira de ciências sociais, v. 14, n. $^{3} 39,1999$. p. $83-102$.

27 O cientista político Fábio Kerche registra que "não é sem motivo que os diferentes lobbies de promotores e procuradores tenham se organizado fortemente para convencer os parlamentares constituintes a garantir e a ampliar o papel da instituição, percebendo a importância desse processo para a construção institucional do Ministério Público." Cf. KERCHE, Fábio. Virtude e Limites: Autonomia e Atribuições do Ministério Público no Brasil. São Paulo: Edusp, 2009, p. 45. 
cionais, que ninguém nunca conheceu.

No entanto, essas importantes constatações críticas realizadas pela Ciência Política, significativas para a constante remodelação do Ministério Público, esqueceram, de algo muito importante, a reflexão sobre as relações raciais que se movimentam dentro e fora da instituição. A crítica política padecia de ausência de criticidade racial. A crise paradigmática ou imagética do Ministério Público ("não sou o que penso que sou enquanto instituição") não se resume a um debate sobre desigualdade de classes sociais. A raça constitui o social no Brasil. Não poderia ser diferente com a sociologia institucional do Ministério Público.

A crise paradigmática do Ministério Público, que é uma crise de efetividade de sua função institucional de proteger a ordem jurídica, deve ser analisada por uma perspectiva crítica racial, que remete à desconstrução do onírico sentimento de democracia racial, que povoa o imaginário da instituição e não o liberta do narcisismo institucional.

Tukufu Zuberi realiza importante reflexão quando, retratando o contexto norte-americano, diz que a extensão da teoria crítica racial para o Direito, cujas bases iniciais se dão na sociologia, permite perceber como a raça é fator determinante para a construção de institutos jurídicos, a defesa de aplicação substancialmente igualitária das leis e a percepção sobre um modo de agir dos juristas, que, mesmo diante dessa relevância temática, colocam a justiça racial como uma política de ressentimento de comunidades afrodescendentes. Tukufu Zuberi denuncia a existência de um projeto acadêmico, político e jurídico, que, por meio de uma "cegueira racial", o que aqui pode ser lida como democracia racial, encontra-se associado a um "iluminismo racial", que apregoa direitos e garantias universais, mas que na prática não compreende a população afrodescendente. ${ }^{28}$

Diante disso, propõe-se, neste artigo, nova crítica institucional, marcadamente político-racial, a partir da análise do quadro racial dos membros do Ministério Público da Bahia e da correspondente dissonância prática que isso pode resultar na proposta constitucional de efetivação de direitos e garantias fundamentais, que, no Brasil, por notoriedade e historicidade de uma abolição inconclusa e formalmente dada em 1888, são direitos e garantias fundamentais de uma imensa população negra. É o que se verá a seguir.

\section{Ministério Público da Bahia, como poder ser assim?}

Indicados os dilemas da origem moderna do Ministério Público, que se deu no século XVIII, e exposto como o processo político de defesa de ideais liberais se atualiza na determinação constitucional do Ministério Público brasileiro, que, normativamente, anuncia ser o novo canal de materialização da democracia, abre-se espaço para a principal análise sobre o Ministério Público: a estrutura racial que nele se estabelece e que interfere, substancialmente, nas vidas que esperam algo humanizante da instituição. Estrutura racial estratificada que tende a se manter intacta por meio do discurso da democracia racial, que, por sua vez, se fortalece com a discursividade da democracia liberal, de igualdade formal universalizante.

Adiante analisar-se-á a estrutura racial do Ministério Público da Bahia, instituição de um Estado que, por metáforas poéticas e musicais, é conhecido como a África brasileira.

A análise se refere às instâncias de poder do Ministério Público: promotores de justiça, procuradores de justiça e órgãos da Administração Superior, que podem ser ocupados por promotores ou procuradores de justiça. Verificar-se-á, também, quanto ao gênero, quem ocupa esses cargos, realizando-se a necessária intersecção entre gênero e raça para que se possa ter uma noção empírica sobre a mobilidade institucional interna quanto à ocupação de espaços de poder institucional. Adota-se o seguinte raciocínio indagativo: negros e negras conseguem ter acesso aos cargos de promotor de justiça? Se sim, são homens ou mulheres

28 ZUBERI, Tukufu. Teoria crítica da raça e da sociedade nos Estados Unidos. Cadernos do CEAS: Revista crítica de humanidades, n. ${ }^{\circ}$ 238, p. 464-487, 2016. 
ou transgêneros? Qual a possibilidade, uma vez dentro da instituição, de ocuparem espaços decisórios como a Administração Superior do Ministério Público?

A estrutura do Ministério Público é relativamente complexa, com distribuição de poder entre órgãos de execução, que são os promotores de justiça, que atuam perante o $1^{\circ}$ grau do Poder Judiciário, e procuradores de justiça, que atuam perante o $2^{\circ}$ grau. Esses membros, por definição da atividade finalística do Ministério Público, exercem seu poder, como regra, para fora da instituição, a fim de atender as necessidades sociais, salvo quando escolhidos para exercer temporariamente funções relativas à Administração Superior, quando passam a se preocupar mais com a organicidade da instituição.

O Conselho Superior do Ministério Público e Colégio de Procuradores são órgãos colegiados pertencentes à Administração Superior. A Corregedoria-Geral, órgão de fiscalização e orientação funcional, e a Procuradoria-Geral — chefia institucional —, por sua vez, integram, respectivamente, a Administração Superior. São nesses órgãos que circulam as principais decisões institucionais do Ministério Público, do ingresso na carreira de promotor de justiça à aprovação da vitaliciedade do membro, da instauração de procedimento administrativo disciplinar à propositura de ação contra alguma autoridade com prerrogativa de foro na Constituição Estadual, por exemplo.

Essa composição encontra-se na Lei Orgânica Nacional do Ministério Público (lei n. 8.625/93), art. $5^{\circ}$ ao $7^{\circ}$. É um estatuto legislativo que serve de parâmetro geral para as leis orgânicas específicas de cada Ministério Público Estadual, a exemplo da Lei Complementar n. ${ }^{\circ}$ 11/96, que rege a estrutura e funções do Ministério Público baiano.

Outros órgãos como os Centros de Apoios Operacionais, Centros de Estudos e Aperfeiçoamento, Ouvidoria e Comissão de Concurso são órgãos auxiliares, e, apesar do designativo nominal auxiliar, são também relevantes para o adequado funcionamento institucional. Não se fará, com exceção do Centro de Estudos e Aperfeiçoamento Funcional (CEAF), a análise da composição racial desses órgãos, que possuem poder de decisão nas temáticas que lhes correspondem, não a ponto de serem considerados pela lei como órgãos da Administração Superior. O critério de análise é a composição racial de órgãos com capacidade decisória significativa, segundo a classificação da Lei Orgânica.

De acordo com informações passadas por e-mail pela Secretaria-Geral do Ministério Público da Bahia, há 583 membros entre promotores e procuradores de justiça. Atualmente, o quantitativo de mulheres supera o de homens, conforme tabela n. ${ }^{\circ} 01$. No quantitativo geral, surgem três universos, considerado o critério de autodeclaração - o próprio membro alimentou o sistema de informação com o dado sobre sua autoconsideração racial: a) 234 membros se autodeclararam pretos e pardos; b) 291 membros se declararam brancos; c) 58 membros declararam pertencer a outra raça.

Como se vê, há preponderância da autodeclaração da raça branca. Embora o IBGE e o Estatuto da Igualdade Racial (art. $1^{\circ}$, parágrafo único, IV, da Lei n. ${ }^{\circ}$ 12.288/2010) considerem população negra o quantitativo dos que se declararam pretos e pardos, optou-se por indicar, também, o quantitativo dos que apenas se declararam como pretos, para que se possa contrastá-lo com o universo geral de 583 membros (tabela 03). Apesar de não se ter conseguido o quantitativo de promotoras e procuradoras brancas e pardas, obteve-se o quantitativo de mulheres pretas que integram a carreira, conforme a tabela n. ${ }^{\circ} 4 .^{29}$

Tabela $01-$ relação gênero/cargo $\quad n=583$

\begin{tabular}{|l|l|l|}
\hline Gênero & Promotor de Justiça & Procurador de Justiça \\
\hline Homens & $258(49 \%)$ & $21(38 \%)$ \\
\hline Mulheres & $269(51 \%)$ & $35(62 \%)$ \\
\hline
\end{tabular}

29 Essa ausência parcial de dados se deu por conta de dificuldades de tempo, pandemia e logística para obtenção de dados no processo de elaboração deste artigo. 


\begin{tabular}{|l|l|l|}
\hline Transgênero & 0 & 0 \\
\hline Total & $527(100 \%)$ & $56(100 \%)$ \\
\hline
\end{tabular}

Fonte: Secretaria-Geral do Ministério Público da Bahia.

Tabela 02: relação raça/cargo $\quad n=583$

\begin{tabular}{|l|l|l|}
\hline Raça & Promotor de Justiça & Procurador de Justiça \\
\hline Pretos e pardos & $210(40 \%)$ & $24(43 \%)$ \\
\hline Brancos & $272(52 \%)$ & $19(34 \%)$ \\
\hline Outra & $45(8 \%)$ & $13(23 \%)$ \\
\hline Total & $527(100 \%)$ & $56(100 \%)$ \\
\hline
\end{tabular}

Fonte: Secretaria-Geral do Ministério Público da Bahia.

Tabela 03: relação raça isoladamente/cargo $n=583$

\begin{tabular}{|l|l|l|}
\hline Raça & Promotor de Justiça & Procurador de Justiça \\
\hline Pretos & $34(6 \%)$ & $2(4 \%)$ \\
\hline Pardos & $176(34 \%)$ & $22(39 \%)$ \\
\hline Brancos & $272(52 \%)$ & $19(34 \%)$ \\
\hline Outra & $45(8 \%)$ & $13(23 \%)$ \\
\hline Total & $527(100 \%)$ & $56(100 \%)$ \\
\hline
\end{tabular}

Fonte: Secretaria-Geral do Ministério Público da Bahia. 
Tabela 04: mulheres pretas/ quadro geral de membros $\mathrm{n}=583$

\begin{tabular}{|l|l|l|}
\hline Raça & Promotor de Justiça & Procurador de Justiça \\
\hline Pretas & $15(3 \%)$ & $2(4 \%)$ \\
\hline Pardas & - & - \\
\hline Brancas & - & - \\
\hline Outra & - & - \\
\hline Total & $527(100 \%)$ & $56(100 \%)$ \\
\hline
\end{tabular}

Fonte: Secretaria-Geral do Ministério Público da Bahia ${ }^{30}$.

Nessa primeira visão geral, desponta o domínio racial branco sobre o quantitativo de membros negros, aqui considerados, conforme classificação usado pelo Instituto Brasileiro de Geografia e Estatística, os que se autodeclararam como pertencentes à população negra e parda.

Outra informação a ser considerada é que, somente a partir do ano de 2014, por ato normativo exarado pelo Procurador-Geral à época, iniciou-se, não sem polêmicas institucionais, a abertura de concursos públicos com a previsão de cotas para negros no acesso à carreira de promotor de justiça. $\mathrm{O}$ ato normativo 544/2014, que aqui se refere, pretendeu implementar no âmbito do Ministério Público baiano as diretrizes da Lei estadual n. ${ }^{\circ}$ 13.182/2014, que instituiu o Estatuto da Igualdade Racial e do combate à Intolerância Religiosa no Estado da Bahia. Essa lei considera população negra, conforme o critério classificatório usado pelo IBGE, pessoas que se autodeclararem pretas e pardas.

No ano de 2014, impugnou-se o referido concurso por meio de representação dirigida ao Conselho Nacional do Ministério Público, questionando-se a implementação de cotas raciais no âmbito do Ministério Público baiano, já que a lei estadual usada se referia, apenas, à Administração Direta Estadual (procedimento de controle administrativo n. $\left.{ }^{\circ} 1283 / 2014-11\right)$.

O Conselho Nacional do Ministério Público entendeu por não acolher a referida representação, ao fundamento de que as cotas raciais têm respaldo constitucional direto, sem necessidade de lei intermediária para implementá-la, tendo o Ministério Público baiano usado a lei estadual somente como parâmetro, o que não significa que estaria submisso, dessa forma, às ingerências do Executivo estadual.

Tal impugnação administrativa sugere o pensamento de como o mito da democracia racial, fantasiado muitas vezes com uma roupagem de discussões legalistas — se aplicável ou não determinada lei — continua a obstaculizar a realização de políticas afirmativas direcionadas à vigília e combate ao racismo institucional. Quando se pretende dar, ainda que tardiamente, um passo mais à frente, há sempre alguém a impugnar o óbvio, porque se coloca em questão privilégios sociais e institucionais reservados à branquitude.

Em junho de 2017, o Conselho Nacional do Ministério Público editou resolução de n. ${ }^{\circ}$ 170/2017, dispondo sobre a reserva aos negros do mínimo de $20 \%$ (vinte por cento) das vagas oferecidas nos concursos públicos para provimento de cargos do Conselho Nacional do Ministério Público e do Ministério Público brasileiro.

A política pública de ação afirmativa, no âmbito do Ministério Público baiano, conseguiu prosseguir no tempo. Em 2018, novo concurso para promotor de justiça foi realizado com a previsão de reserva de 30\% de vagas para os que se autodeclarassem negros.

Ainda assim, as cotas não têm sido suficientes para afastar o racismo estrutural que formata o desenho institucional do Ministério Público da Bahia. Conforme informações fornecidas pelo Centro de Estudos e Aperfeiçoamento do Ministério Público baiano (CEAF), no concurso de 2014, foram aprovadas 48 pessoas, das quais apenas 07 conseguiram ter acesso pelas cotas raciais, dentre estes não havia mulheres, conforme elucida tabela n..$^{\circ}$ 05. Em 2018, houve 75 aprovados, dentre os quais apenas 03 tiveram acesso por meio das

\footnotetext{
30 Não foi possível obter informações sobre o quantitativo de promotoras e procuradoras de justiça brancas e pardas e outras. Ainda assim, entendeu-se pertinente expor o quantitativo de promotoras e procuradoras que se autodeclararam pretas, para que se possa avaliar a representatividade de gênero/raça na instituição, considerado o quadro geral de 583 membros,
} 
cotas, dentre estes havia, apenas, uma mulher negra, conforme tabela n. ${ }^{\circ} 06$.

Tabela n. ${ }^{\circ} 05$ - concurso para promotor de justiça/2014

\begin{tabular}{|c|c|c|c|c|}
\hline Sexo & Ampla concorrência & $\begin{array}{l}\text { Pessoas com } \\
\text { deficiência }\end{array}$ & Negros & Total \\
\hline Masculino & 30 & 1 & 7 & 38 \\
\hline Feminino & 10 & 0 & 0 & 10 \\
\hline \multirow[t]{2}{*}{ Total } & 40 & 1 & 7 & 48 \\
\hline & \multicolumn{4}{|c|}{ Tomaram posse- Turma única (50 vagas) } \\
\hline Masculino & 26 & 1 & 7 & 34 \\
\hline Feminino & 9 & 0 & 0 & 9 \\
\hline Total & 35 & 1 & 7 & 43 \\
\hline
\end{tabular}

Fonte: Centro de Estudos e Aperfeiçoamentos do Ministério Público da Bahia (CEAF/BA).

Tabela n. ${ }^{\circ} 06$ - concurso para promotor de justiça/2018

\begin{tabular}{|l|l|l|l|l|}
\hline Sexo & Ampla concorrência & Pessoa com deficiência & Negros & Total \\
\hline Masculino & 43 & 1 & 2 & 46 \\
\hline Feminino & 28 & 0 & 1 & 29 \\
\hline Total & 71 & 1 & 3 & 75 \\
\hline Masculino & Tomaram posse $-1^{\mathbf{a}}$ turma (25 VAGAS) & 2 & 15 \\
\hline Feminino & 12 & 1 & 1 & 10 \\
\hline Total & 9 & 0 & 1 & 3 \\
\hline
\end{tabular}

Fonte: Centro de Estudos e Aperfeiçoamentos do Ministério Público da Bahia (CEAF/BA).

Em relação ao concurso do ano de 2018, houve um fato referente à posse dos novos promotores, ocorrida em janeiro de 2020, que se relaciona com muita pertinência à temática em análise. Costumeiramente, o discurso de posse é realizado apenas por quem tenha conseguido a primeira colocação. Não foi o caso do concurso de 2018. O discurso foi repartido entre o primeiro colocado, uma mulher negra, a única nessa condição, e uma pessoa com deficiência, o único aprovado nessa condição. A ideia era mostrar a diversidade do Ministério Público da Bahia, que ficaria patente com essas representatividades: um branco em primeiro lugar, a única mulher negra aprovada e a única pessoa com deficiência. A novíssima promotora de justiça negra, naturalmente orgulhosa com a posse que ali se dava, pronunciou tais palavras:

esse momento, nosso momento, é prova concreta da pluralidade inerente ao Estado da Bahia, em sua constante busca pela igualdade e elevação da cultura negra e de todos as minorias, sobretudo através dessa instituição. O Ministério Público da Bahia vem ao longo dos anos apresentando uma atuação em prol da comunidade negra e em prol de todos os demais setores marginalizados pela sociedade visando a uma real mudança. Essa excelente atuação incita um sentimento ainda maior de orgulho e gratidão pela oportunidade de ingressar em seus quadros, de fazer parte dessa luta, sentimento esse que é compartilhado por todos nós. É oportuno lembrarmos que não obstante sejamos grande parcela da população brasileira, poucos são os promotores negros, menor ainda é a porcentagem de promotoras negras. O caminho do concurso público é árduo, embora gratificante. Mas ainda é mais árduo para aqueles que são invisibilizados pela sociedade. ${ }^{31}$

31 Minuto 3.03 a 4.12 do discurso de posse de promotores de justiça em 2020, disponível em https://www.youtube.com/ 
Sem qualquer intenção de desprestigiar o belo momento que é a posse em um cargo público, a reflexão que se faz, com esses primeiros dados coletados, é de que, diversamente do que foi enunciado no discurso, a posse de uma única mulher negra, e somente ela, cujo acesso se deu por cotas, não comprova a suposta pluralidade inerente ao Estado da Bahia, mas sim de como o Ministério Público da Bahia, mesmo com implementação de cotas raciais, continua a repetir a opressão transhistórica que o constitui: racismo institucional e domínio de poder pela branquitude patriarcal.

Cotas raciais são importantíssimas e necessárias ao processo de reparação e reconhecimento da população negra. Não são pontos de chegada da negritude. São possíveis pontos de partida. Não podem ser vistas como o exaurimento de uma política pública afirmativa de uma instituição, principalmente o Ministério Público, de vocação abertamente democrática. Pessoas negras, em cargos concebidos socialmente como relevantes, as ditas carreiras de Estado, não podem ser vistas como peças de embelezamento negro de um tabuleiro branco de xadrez. Devem, naturalmente, ocupar cargos e desempenhar funções de alta decidibilidade institucional, capaz de definir os novos rumos da instituição. Devem ser estruturas pensantes e de ação de uma nova concepção institucional, focada em destruir o racismo de dentro para dentro na instituição e, como é de se esperar, fora da instituição também.

Não é o que se vê no Ministério Público da Bahia, que do ano de 1935 ao início de 2020, teve 32 Procuradores-Gerais, tendo sido 30 do gênero masculino e dois do gênero feminino, de qualquer sorte todos não negros. Isso indica que a chefia da instituição, o principal cargo do Ministério Público, esteve, e continua, sob o comando de pessoas não-negras e, nesse universo, sob a batuta ideológica de uma eterna branquitude que se pereniza no poder institucional. ${ }^{32}$ Poder que se mostra masculino, mesmo tendo-se atualmente um quantitativo maior de mulheres na instituição.

Teriam essas pessoas o olhar adequado para determinar ações institucionais que abordem a centralidade da questão racial que divide a sociedade brasileira, em especial a baiana, em todos os pontos de seu fluxo histórico, do privado ao público?33

O Centro de Estudos e Aperfeiçoamento do Ministério Público da Bahia (CEAF), quando consultado, por e-mail, sobre quem foram (gênero e raça) seus dirigentes desde o período de sua fundação, informou relação que indica que, do ano de 1996 a 2020, houve 13 dirigentes, dos quais, apenas, duas mulheres brancas e um homem negro.

A sugestão que aparece é que, se promotores e promotoras entram na instituição desavisados sobre a problemática racial, tendem a permanecer nesse estado de letargia, pois os eventos institucionais promovidos pelo CEAF, destinados a abordar a questão racial, se concentram na semana do dia 20 de novembro, repetindo certa caricatura comemorativa que acontece em outras instituições do país por conta daquele data, denominada de dia da consciência negra. O negro e negra sabem, no fundo da alma, que dia de consciência negra é todo dia, vigília constante sobre a sua condição negra, embora se permita comemorar aquela data.

Acompanhando-se as informações prestadas pela Secretaria-Geral, soube-se que, na formação atual do Conselho Superior do Ministério Público, há 9 procuradores de justiça eleitos pela classe, dos quais 5 são

watch?v=YYLczXnK7Rk\&t=141s. Acesso em:22 mai. 2020.

32 De acordo com censo racial realizado pelo Ministério Público de São Paulo (Relatório de Levantamento Estatístico- 2015), constatou-que 93\% dos membros do Ministério Público Paulista se declararam brancos e 4\% pretos, sendo que, entre os servidores do MP/SP, $80 \%$ se declararam brancos e 14\% pretos. Disponível emhttp://www.mpsp.mp.br/portal/page/portal/GT_Igualdade_ Racial/Cotas_Raciais/RELATÓRIO\%20DE\%20LEVANTAMENTO\%20CENSO\%20RACIAL.pdf. Acesso em: 11 ago. 2020. Em 17 de março de 2017, o Ministério Público Federal ajuizou ação civil pública contra a União, impugnando o $29^{\circ}$ concurso para procurador da república, ao fundamento de que no edital do concurso não havia previsão de cotas para pessoas negras. Destacouse, na ação civil pública, que apenas 14\% do membros do Ministério Público Federal são negros, contabilizados negros e pardos, e que não havia sequer uma procuradora da república preta. Disponível em http://www.mpf.mp.br/df/sala-de-imprensa/docs/ acp-concurso-procurador-mpf. Acesso em 05. out. 2020.

33 Informações obtidas no Memorial virtual do Ministério Público da Bahia, disponível em http://www.memorial.mpba.mp.br/ procuradores-gerais-de-justica/. Acesso em: 25 mai. 2020. 
mulheres e 04 homens. Dentre as mulheres, há três que se autodeclararam pretas ou pardas, entre os homens todos se declararam brancos. A Corregedora Geral atual é branca, assim como a Procuradora-Geral, que são membros natos do Conselho Superior. Mulheres no poder, algo positivo sim, porém não negras.

Por isso, muito preciosa a reflexão trazida por Jonata Wiliam Sousa da Silva, que, preocupado com a necessidade de ocupação de espaços de poder por pessoas negras, e depois de exercer uma precisa leitura de dados sobre o perfil racial do Ministério Público de São Paulo, das Defensorias Públicas e da advocacia brasileiras, conclui que a "hegemonia branca nas funções pública e privada que promovem a 'justiça ' resulta em opressão e controle social da população negra, notadamente através do sistema de justiça criminal ${ }^{34}$ ”.

Seria possível uma mudança de estrutura de pensamento do Ministério Público Baiano se o Centro de Estudos e Aperfeiçoamentos continua sendo dirigido por pessoas não negras vinculada à concepção branca de se entender o mundo? Seria possível essa mudança, se os cursos de aperfeiçoamento do Ministério Público tendem a não realizar intersecções entre pautas jurídicas dogmáticas e questões raciais ${ }^{35}$ ?

$\mathrm{Na}$ fixação de atribuições das promotorias de justiça, os temas "combate ao racismo" e "promoção da igualdade racial" não são explicitados nas diversas promotorias que integram o Estado. Há de ser decifrado interpretativamente de alguma outra atribuição, como a criminal ou a de proteção de direitos difusos e coletivos (cidadania). Conforme informação passada pela Secretaria-Geral do Ministério Público, há, em Salvador, a $2^{a}$ Promotoria de Justiça de Cidadania, responsável genericamente pela temática racial, e o Grupo de Atuação Especial de Proteção dos Direitos Humanos e Combate à Discriminação - GEDHDIS, com atuação mais específica sobre o tema, o que é muito pouco, considerada a complexidade da problemática racial.

Não se trata de desprezar trabalhos hercúleos de promotores e promotoras de justiça que realizaram excelentes atuações no combate ao racismo e suas múltiplas formas de existir. Há de se pensar e lutar por uma previsão expressa dessa atribuição (combate ao racismo) para todas as promotorias de todas as regiões e microrregiões da Bahia, uma vez que a antinegritude é estrutural e não poupa espaços de convivência. Onde houver ar respirável, é possível que o racismo o abafe com sua perversidade.

Não se pode ocultar também a belíssima vitória que coube, em 22 de agosto de 2019, ao Ministério Público do Estado da Bahia, que foi vencedor, com o inovador aplicativo Mapa do Racismo, de um concurso de boas práticas institucionais realizado pelo Conselho Nacional do Ministério Público, referente à categoria "Comunicação e Relacionamento". ${ }^{36}$ Trata-se de aplicativo que permite ao cidadão registrar, rapidamente, uma situação de discriminação racial.

Em julho de 2020, o Ministério Público da Bahia criou grupo de trabalho destinado à elaboração de programa de enfrentamento ao racismo institucional:

no dia que se celebra dez anos da criação do Estatuto da Igualdade Racial, o Ministério Público do Estado da Bahia instituiu um Grupo de Trabalho (GT) para elaboração de um programa de enfrentamento ao racismo nos quadros da instituição. Fazem parte do GT, cujo ato foi publicado no Diário Oficial da Justiça dessa segunda-feira (20), promotores e promotoras de Justiça, além de servidores e servidoras que integram a chefia de gabinete da Procuradoria-Geral de Justiça; a coordenadoria e superintendência de Gestão Administrativa; a diretoria de Gestão de Pessoas; a coordenação do Centro de Estudos e Aperfeiçoamento Funcional (Ceaf); a coordenação do Centro de Apoio Operacional dos Direitos Humanos (CAODH); a coordenação do Grupo de Atuação Especial de Proteção dos Direitos Humanos e Combate à Discriminação (Gedhis); a Associação do Ministério Público do Estado da Bahia (Ampeb); o Sindicato dos Servidores do Ministério Público do Estado da Bahia (Sindsemp); além de integrantes do Coletivo Maria Felipa, entidade antirracista autônoma e independente criada

\footnotetext{
34 C.f SILVA, Jonata Wiliam Sousa da Silva. Sistema de Justiça Criminal e a questão racial: caminhos para a ocupação de pessoas negras nos espaços de poder. In: Enegrecendo o Direito. Questões raciais no Brasil. Coord. Julio Rocha. p. 121-132. Salvador: Mente Aberta, 2020. 35 Desde julho de 2016, tem acontecido, no Ministério Público da Bahia, o seminário "Biopolíticas e Mulheres Negras", com abordagem interseccional e valorização do feminismo negro no Brasil e na América Latina, uma iniciativa do Grupo de Atuação Especial em Defesa da Mulher e da População LGBT (Gedem). Esse seminário já está na $5^{a}$ edição (2020) e é aberto ao público.

36 Informações disponíveis em https://www.mpba.mp.br/noticia/47912. Acesso em: 22. mai. 2020.
} 
por servidores, colaboradores e estagiários que atuam no MP, com o objetivo de promover o debate e a conscientização sobre o racismo nas suas mais diversas formas, em especial o racismo institucional ${ }^{37}$.

Essas ações institucionais positivas, no entanto, são silenciosamente minadas por uma dimensão institucional antinegra. Verifica-se ausência de mobilidade institucional dos negros e negras que, na qualidade de promotores e promotoras, não conseguem, mesmo após o transcurso de décadas, ocupar posicionalidades de liderança institucional. As possibilidades se tornam impossíveis quando há intersecção entre raça negra e gênero feminino.

Percebe-se que, mesmo com uma presença feminina numericamente maior que a masculina, é praticamente inexistente a presença de promotoras e procuradoras negras em funções de alto poder decisório dentro Ministério Público. O Ministério Público da Bahia nunca teve uma Procuradora-geral de justiça negra, nem mesmo um Procurador-Geral de Justiça negro. Em sua história de chefia institucional, só contou com três mulheres na função de Procuradora-Geral, todas não negras ${ }^{38}$.

Nesse ponto, a advertência de Angela Davis ${ }^{39}$ é muito importante quando enfatiza a necessidade de que seja feita uma pesquisa séria, do ponto de vista histórico, sobre a experiência das mulheres negras escravizadas para que se compreenda, adequadamente, que a luta atual das mulheres negras e de todas as mulheres se dá em busca de emancipação, e que as mulheres negras nunca foram submissas e voluntariosas com a escravidão. É compreender, com Carla Akotirene ${ }^{40}$, como o cisheteropatriarcado, capitalismo e racismo coexistem como modeladores das subjetividades atuais. Entender que a interseccionalidade do feminismo negro aponta para uma riqueza epistêmica na compreensão do mundo. Buscar em Bell Hooks ${ }^{41}$ o poder de uma educação como prática libertária, que recuse essencialismos e não endosse hierarquias opressivas convencionais. É a difícil tarefa de educar politicamente a instituição Ministério Público nesse sentido de pensar.

Ainda sobre a necessidade de um feminismo negro dentro da própria instituição, é importante recordar o que foi dito por Patricia Hill Collins, em busca de um conceito de outsider within para encontrar a significação sociológica do feminismo negro:

nas biografias dos brancos ricos, é frequente o relato de seu amor por suas "mães" negras, enquanto os relatos das trabalhadoras domésticas negras ressaltam a percepção de autoafirmação vivenciada pelas trabalhadoras ao verem o poder branco sendo desmistificado - saberem que não era o intelecto, $\mathrm{o}$ talento ou a humanidade de seus empregadores que justificava o seu status superior, mas o racismo.

No entanto, por outro lado, essas mesmas mulheres negras sabiam que elas jamais pertenceriam a suas "famílias" brancas. Apesar de seu envolvimento, permaneciam como outsiders. ${ }^{42}$

\footnotetext{
37 Informações disponíveis em https://www.mpba.mp.br/noticia/52493. Acesso em 05. out. 2020. No Conselho Nacional do Ministério Público, há a Comissão de Defesa dos Direitos Fundamentais, na qual funciona o Grupo de Trabalho Enfrentamento ao Racismo e Respeito à Diversidade Étnica e Cultural.

38 Ao analisar outros ambientes institucionais, como os Poderes Legislativo e Executivo, com destaque para o período eleitoral de 2014 e 2016, Rafael Moreira e Marli da Costa discorrem sobre os impedimentos sociais, restrições e desafios que envolvem a participação política da mulher na sociedade brasileira, dividida em classes e determinada pelo capitalismo. C.f MOREIRA, Rafael Bueno da Rosa; COSTA, Marli Marlene Morais. As mulheres no contexto da sociedade de classes e sua participação política no processo legislativo e executivo do Brasil: das restrições e desafios. Revista Brasileira de Políticas Públicas, v. 9, n. 1, p. 34-54, 2019. Quanto à situação específica das mulheres negras no cenário brasileiro, Jurema Werneck lembra que "sabemos que tem sido a partir de condições profundamente desvantajosas em diferentes esferas que as mulheres negras desenvolveram e desenvolvem suas estratégias cotidianas de disputa com os diferentes segmentos sociais em torno de possibilidades de (auto)definição. Ou seja, de representação a partir de nossos próprios termos, a partir do que se projetam novos horizontes. Estratégias que deviam e devem ser capazes de recolocar e valorizar nosso papel de agentes importantes na constituição

do tecido social e de projetos de transformação." C.f WERNECK, Jurema. Nossos passos vêm de longe! Movimentos de mulheres negras e estratégias politicas contra o sexismo e o racismo. in: Mulheres negras: um olhar sobre as lutas sociais e as políticas públicas no Brasil. Org. Jurema Werneck. Rio de Janeiro: Criola, 2010. p. 76-86.

39 DAVIS, Angela Y. Mulheres, raça e classe. Trad. Heci Regina Candiani. 1ª ed. São Paulo: Boitempo, 2016. p. 17.

40 AKOTIRENE, Carla. Interseccionalidade. São Paulo: Polén, 2019. p. 51.

${ }^{41}$ HOOKS, Bell. Ensinando a transgredir: a educação como prática da liberdade. Trad. Marcelo Brandão Cipolla. $2^{a}$ ed. São Paulo: Martins Fontes, 2017. p. 105.

42 COLLINS, Patricia Hill. Aprendendo com a outsider within: a significação sociológica do pensamento feminista negro. Sociedade e Estado, v.
} 
Por isso, é muito importante quando Livia Sant anna Vaz, em respeito à força do feminismo negro e ao destacar uma correta leitura sobre uma justiça étnico-racial interseccional, reafirma que " eu, mulher negra, não sou sujeito universal!” e lembra, com vigor, que "no Brasil, talvez o Direito seja uma das áreas do conhecimento mais coloniais e epistemicidas" e que esse epistemicídio jurídico se dá pela permanência de uma lógica moderna/colonial de produção do conhecimento, que invisibiliza os conhecimentos produzidos pelas populações afrodiaspóricas e indígenas também. ${ }^{43}$

A propósito, ao enfatizar as (dis) funções da linguagem na proteção à dignidade de gênero, Ana Gabriela Souza Ferreira indica que, mesmo diante da constante luta histórica de movimentos feministas, "a própria definição de direitos humanos hodierna continua a absorver conceitos discrepantes da associação de linguagem que divide "mundo masculino" e "mundo feminino". Ou seja, a linguagem universalizante do discurso de direitos humanos é insuficiente para tratar da temática gênero ${ }^{44}$.

Registre-se, ainda, que não há promotores de justiças e promotoras de justiça transgêneros.

Haveria futuro para uma perspectiva afrocentrada e interseccional (raça e gênero) no poder institucional do Ministério Público?

Multirracialidade institucional, com agregação significativa de pessoas negras que, uma vez no poder, possam exercer novos poderes estruturantes e reconfiguradores da sociedade — para a branquitude são poderes antigos - , apresenta-se como um caminho de difícil execução na atual vivência institucional do Ministério Público da Bahia.

Tem prevalecido o domínio racial da branquitude, com a vivência - e não a convivência, que supõe a ideia de comunidade institucional—, deslocada, desconfortável, e existencialmente desgastante de uns poucos promotores negros e negras que, sem mesmo saberem quantos negros e negras compõem a instituição, exercem suas funções institucionais num arquipélago de promotores e promotoras de justiça não negros, que admiram algo folclórico da cultura negra, samba, quitutes e corpos que balançam. Param por aí.

Esse é um pensamento possível de se ler com os dados até então obtidos e expostos neste artigo.

\section{0 duplo insulamento, a dupla ausência e a antinegritude institucional}

Os dados até então apresentados indicam como promotores e promotoras negras estão cercados por outros promotores e promotoras não negros, marcadamente brancos e brancas, a despontar, nessa diferença de quantitativos raciais, a imagem que sugere o título do presente artigo: ilhas negras que mancham um arquipélago não negro. Imagem que se constrói com base na preponderância racial branca, que solicita a ausência negra ou depende da pequeniníssima existência desta para autorizar o teatro democrático do agir institucional branco.

A presença de certa negritude, que não ocupa, e está destinada quase que fatalmente a não ocupar posicionalidades de liderança institucional, segundo indica a própria historicidade institucional, permite dizer que, mesmo ao ostentar boa condição financeira e social obtida pelos vencimentos estimados em R $\$$ $25.000,00$, esse negro e essa negra estão submetidos a uma sociologia institucional que os interpreta como coisa, como arremate pigmentado, e, por isso mesmo, desprezível, de um quadro institucional que seguiria naturalmente seu percurso sem preocupações inclusivas sobre a negritude.

\footnotetext{
31, n. ${ }^{\circ}$ 1, p. 99-127, 2016.

43 VAZ, Livia Sant’anna. Eu, mulher negra, não sou um sujeito universal. Disponível em https://www.jota.info/opiniao-e-analise/artigos/eu-mulher-negra-nao-sou-sujeito-universal-12082020. Acesso em: 12. ago. 2020.

44 FERREIRA, Ana Gabriela Souza. As disfunções da linguagem na proteção à dignidade de gênero - a inexistência do bumano feminino no processo penal. Disponível em https://www.academia.edu/37482217/AS_DIS_FUN\%C3\%87\%C3\%95ES_DA_LINGUAGEM_ NA_PROTE $\%$ C3 $\% 87 \%$ C3\%83O_\%C3\%80_DIGNIDADE_DE_G\%C3\%8ANERO_A_INEXIST\%C3\%8ANCIA_DO_HUMANO_FEMININO_NO_PROCESSO_PENAL. Acesso em: 10 ago. 2020.
} 
Ao se assim pensar, mais do que afirmar sobre a problemática presença de negros e negras no mundo branco, deve-se marcar neste artigo o pensamento de que promotores e promotoras, na mesma lógica do que acontece fora da instituição, estão inseridos em uma antinegritude e antagonismo estruturais. Conforme explica João Costa Vargas, a antinegritude ultrapassa o binômio brancos e não brancos para resultar na díade negros e não negros, da qual também se faz uso no presente artigo.

Referido autor explica que:

a díade negro/não negro, no entanto, representa um contínuo mais amplo da Humanidade que inclui pessoas não-brancas e não-negras, como asiáticos, indígenas, e latinos (nos Estados Unidos). Nesse contínuo mais abrangente, graus de Humanidade não são conferidos a partir da branquitude, mas em relação à distância relativa da negritude. O conjunto da Humanidade, então, inclui pessoas brancas bem como pessoas não-brancas e nãonegras. Ser humano é ser não negro. A díade negro/não-negro condensa os princípios da antinegritude, uma lógica relacionada mas distinta da supremacia branca. Relacionada porque a antinegritude, como a supremacia branca, de fato mantém pessoas negras e brancas em polos opostos de valor humano; mas distinta porque, de acordo com aantinegritude (que exploraremos abaixo), a referência fundamental é a não pessoa negra uma referência ausente, uma não-referência. Uma não referência eficaz, poderosa e transhistórica. Essa nãoreferência à não pessoa negra faz com que, não somente brancos, mas todas pessoas não negras, derivem sua subjetividade e seus privilégios sociais relativos do fato de não serem negras. A pessoa negra, assim, não faz parte da Humanidade; essa pessoa torna possível mas não é parte da hierarquia Humana. ${ }^{45}$

Apesar de integrarem formalmente a instituição, negros e negras estão substancialmente alijados das grandes funções decisórias do Ministério Público, situação que se torna exponencialmente drástica, quando a historicidade do Ministério Público da Bahia sinaliza uma trajetória que tem se mostrado impossível para a mulher negra: ocupar o cargo de Procuradora-Geral de Justiça, por exemplo.

Dentro da instituição, além de ser uma não referência humana para ocupar posicionamentos de alta decidibilidade institucional, o que caracteriza a antinegritude institucional, esse negro promotor de justiça e essa negra promotora de justiça têm, como regra, sua expectativa de vida institucional reduzida a um único momento: o acesso ao cargo público. Logo, é uma não expectativa, porque se refere ao passado.

Ao pensar em um temporalidade presente que lhe parece existir na instituição, e ao pensar em futuro institucional desde logo abortado em seu psiquismo fraturado, esse negro e essa negra vivem da feliz recordação que, alguma dia, o fez representativo para os seus: o acesso ao cargo público. Pode até sonhar com um mundo institucional maior, algo de notoriedade na carreira — ser procurador de justiça ou Procurador-Geral de Justiça. Não consegue verbalizá-lo ou lutar efetivamente por esse sonho, porque o sonho surge imediatamente reduzido ao nada, ao impossível de seu ser. É que a força institucional antinegra congela sua mobilidade institucional e destroça seu as entranhas de seu psiquismo.

Forçadamente acostumado à coisificação social, só lhe resta voltar, no campo da imaginação, ao passado, àquele momento lacrimoso: o acesso ao cargo público. Seguirá, efetivamente, sem condições de liderar a instituição, afogado pela não-negritude, já acostumada a liderar sendo costumeiramente branca.

Nesse momento, devem ser recordadas as palavras de Vinicius de Souza Assumpção, que elabora o irrefutável pensamento:

do corpo à psique, a opressão se apresenta com peculiaridades. O legado racista diuturnamente atualizado reverbera no âmbito psicológico e representa substrato suficiente para a construção de obstáculos impostos, autoimpostos e aceitos no nível inconsciente de todas pessoas (negras e brancas). ${ }^{46}$

A negritude que toma posse no cargo de promotor/a de justiça tende a passar pela condição do negro/a antilhano que se apresenta na universidade parisiense, como foi bem retratado por Franz Fanon. Acha-se

45 VARGAS, João Costa. Por uma mudança de paradigma: antinegritude e antagonismo estrutural. Revista de Ciências Sociais. Fortaleza, v.48, n. 2, jul./dez., 2017 p.83-105.

46 DE SOUZA ASSUMPÇÃO, Vinícius. A gestão do corpo negro no Brasil: da democracia racial ao genocídio. Revista de Criminologias e Políticas Criminais, v. 3, n. ${ }^{\circ}$ 1, p. 20-41, 2017. 
europeu e assimilado pacificamente pelo mundo branco. Na primeira inconveniência de alguma aparição social — seminários, professorado, casamento com brancos/as — lhe será recordado, de forma jocosa ou não, seu estado de coisa, sua matriz colônia e selvagem, ainda que esteja ali intelectualmente superior ao não negro.

\section{As palavras de Fanon emocionam: ${ }^{47}$}

como assim? No momento em que eu esquecia, perdoava e desejava apenas amar, devolviam-me, como uma bofetada em pleno rosto, minha mensagem! O mundo branco, o único honesto, rejeitava minha participação. De um homem exige-se uma conduta de homem; de mim, uma conduta de homem negro ou pelo menos uma conduta de preto. Eu acenava para o mundo e o mundo amputava meu entusiasmo. Exigiam que eu me confinasse, que encolhesse.

Isolados quantitativamente no arquipélago não negro, o que mostra o primeiro isolamento institucional da negritude, surge um segundo insulamento dessa negritude, que decorre do típico exercício das funções de promotores/as de justiça, que se deslocam sozinhos para atuar em comarcas interiorizadas, distantes da sede do Ministério Público. Passam anos nessa condição e sem contato presencial entre si, reservados episodicamente a comemorações institucionais natalinas e de boas-novas sobre o ano institucional que virá. Esse promotor/a negro (a) somente tem ao seu dispor contatos com os colegas por meio de aplicativo de conversas virtuais e redes sociais.

Agrava-se a situação quando esse promotor (a), nesse ambiente, tende a não ter contato com seus colegas negros, e , com isso, está longe da possibilidade de aquilombar-se institucionalmente. Como a instituição não divulga o perfil racial de seus membros e, infimamente, debate as questões raciais que lhe são evidentes, porque as considera superadas, tem-se isolamento institucional antinegro em sua versão crônica. Crível a hipótese de que promotor (as) negros (as) não saibam quantos são os seus pares negros e negras que pertencem à instituição e quem efetivamente o são. Não se constitui dentro da instituição um coletivo que estimule uma consciência negra sobre a vivência institucional.

Nessa dinâmica de vida institucional, negros e negras pouco se cumprimentam. Pouco sabem sobre a própria condição de não pessoa institucional. Por outro lado, os promotores não negros, insistentemente brancos, seguem com seus privilégios institucionais, decorrentes desse antagonismo estrutural que movimenta a instituição. Ausente de si, por ter sua subjetividade negada pelo desprezo social e institucional exercido pelo não negro, dá-se a segunda ausência - a impossibilidade de se espalhar na instituição nos grandes espaços decisórios.

A estrutura institucional invisibiliza vidas negras que estudaram para ser tornar provedores (as) de justiça, e são, contraditoriamente, vistas como símbolos reais de poder pelos que estão de fora e apostam estar bem representados quando visualizam esses negros. Só que esses negros e negras que aí estão, em regra, apenas integram, esteticamente, a instituição, sem saber que compartilham, com seu silêncio e ausência da vida institucional, de uma natural estratégia antinegra de impedir a existência de grandes lideranças negras, e só absorvê-los como pontos negros que cintilam a mentira da democracia racial.

Dá-se a diáspora negra dentro da própria instituição, pretos e pretas perdidos nos marfins da instituição. Casualmente, se o tempo do acaso lhes permitir, segredam-se dores pelos olhos, como se ali o não dito doloroso encontrasse na fuga do instante o cheiro de mar negreiro.

Outra estratégia antinegra é alocar, de maneira caricatural, negros e negras em funções tipicamente voltadas para o combate à discriminação, sem, contudo, reconhecê-los (as) em outras funções de relevância que não versem necessariamente sobre a questão racial. Nessa estratégia particular, dá-se o folclore institucional.

Segundo a estética asfixiante imposta pela branquitude, assim como pessoas negras são as ideais para representar o saci-pererê ou cantigas de ninar do boi-boi da cara preta, também são os rostos necessários

\footnotetext{
47 FANON, Frantz. Pele negra, máscaras brancas. Salvador: Edufba, EDUFBA, 2008. p.107.
} 
para ocupar a celebrações institucionais na semana de 20 de novembro.

Toques, retoques de tambores, coros e cantigas que evocam uma África baiana, na efusão de entreolhares que ludibriam os que estão de fora da instituição e os fazem pensar que, ali no Ministério Público baiano, não existe racismo. Nessa semana da consciência negra, parece que todos querem confessar alguma coisa sobre o racismo, porém o silêncio narcísico da branquitude consegue ressoar mais forte do que os estridentes timbales, abafando-os.

A antinegritude é perversamente sagaz. Tira da negritude a confiança sobre seu passado, oferecendo-lhe, ao incorporá-la a um poder instituído, a sensação de vitória sobre si mesmo, de sacrifício heroico, de expurgo emocional, para adiante imobilizá-la, não referenciá-la, dizer-lhe - à negritude institucionalizada com um certo poder — que só poder ir até determinado limite, o necessário para colorir a democracia interna institucional. Instituições como o Ministério Público ainda seguem com a lógica interpessoal segregacionista e absorvida no autoengano do discurso de mestiçagem, ${ }^{48}$ que conquistou a sociedade brasileira, ainda incapaz de se despir da encardida camisa que contém a expressão democracia racial em destaque.

\section{Uma concepção viável de Ministério Público: constitucionalmente amefricano e quilombista}

As noções históricas, anteriormente lançadas, indicam as ideias e ideais que influenciaram a formatação do Ministério Público brasileiro, que tem na Bahia seu Ministério Público mais antigo, porque na Bahia se implementou o Tribunal da Relação do Estado do Brasil em 07 de março de 1609, para o qual foi prevista a figura do promotor de justiça, responsável ainda pela proteção de interesses da Coroa e do Fisco, a exemplo do que estava estabelecido nas Ordenações Manuelinas (1521) e Ordenações Filipinas (1603), normativas de Portugal que, durante muito tempo, até a cisão da dependência político-jurídica do Brasil em relação a Portugal, regeram as relações sociais que ocorriam na colônia brasileira. ${ }^{49}$

Analisar o perfil racial dos membros do Ministério Público baiano, sediado que está na localidade em que aconteceu um dos principais movimentos insurgentes do país, a revolta dos malês de 1835 é fundamental para se saber o potencial de efetiva participação negra no ambiente institucional. Se na Bahia, conhecida por uma densidade populacional negra, não há participação significativa de negros e negras em cargos institucionais de liderança, em qual Estado haverá então? Sobre a importância da Revolta dos Malês, para uma cultura de opressão colonial, desenvolveu-se forte cultura de resistência escrava, que deve ser contada à negritude contemporânea, como estímulo histórico ao rompimento do ciclo de silêncio opressor exercido pelas elites, a um só tempo neoliberal e neocolonial, que mortifica o processo de subjetivação negra nos espaços institucionais e no cotidiano da vida social.

\footnotetext{
48 Kabengele Munanga nota que "a mestiçagem, como articulada no pensamento brasileiro entre o fim do século XIX e meados do século XX, seja na sua forma biológica (miscigenação), seja na sua forma cultural (sincretismo cultural), desembocaria numa sociedade uniracial e unicultural. Uma tal sociedade seria construída segundo o modelo hegemônico racial e cultural branco ao qual deveriam ser assimiladas todas as outras raças e suas respectivas produções culturais. O que subentende o genocídio e o etnocídio de todas as diferenças para criar uma raça e uma nova civilização, ou melhor, uma verdadeira raça e uma verdadeira civilização brasileiras, resultantes da mescla e da síntese das contribuições dos stocks raciais originais. Em nenhum momento se discutiu a possibilidade de consolidação de uma sociedade plural em termos de futuro, já que o Brasil nasceu historicamente plural.” Cf. MUNANGA, Kabengele. Rediscutindo a mestiçagem no Brasil: identidade nacional versus identidade negra. 5.ed. Belo Horizonte: Autêntica, 2019. p. 91. De acordo com Iraneide Soares, a partir da década de 50, no Brasil, intelectuais negros, no cenário acadêmico, começaram a criticar veementemente essa ideia pacífica de uma mestiçagem brasileira, passando a usar metodologias de pesquisa, bem como produzir textos, relacionadas ao seu modo de estar no mundo, que considerasse a superação de uma desigualdade racial, com acesso de negro ao poder. Desenvolvia-se, então, uma afro-filosofia. C.f DA SILVA, Iraneide Soares. A Trajetória dos Estudos sobre Relações Raciais no Brasil. Padê: Estudos em filosofia, raça, gênero e direitos humanos, v. 1, n. ${ }^{\circ}$ 1, 2007.

49 Informação disponível em http://www.memorial.mpba.mp.br/historia-do-mp/. Acesso em: 25 mai. 2020.
} 
Por isso, honrando-se essa tradição insurgente, é do Ministério Público da Bahia que deve surgir o exemplo de um Ministério Público brasileiro diferenciado, que propague um agir de contrariedade à antinegritude institucional. Deve-se pensar em um modelo dinâmico de Ministério Público, que prospere, com sabedoria e equanimidade, uma justiça racial/gênero internamente e fora da instituição.

A justiça racial interna na instituição com acessibilidade fluida de negros e negras promotores de justiça a cargos e funções de decidibilidade institucional — Procuradoria-Geral de Justiça, Corregedoria-Geral de Justiça e Conselho Superior do Ministério Público —, permitirá, de forma mais eficaz e inclusiva, a realização de uma justiça racial que, fora dos portões da torre ministerial, compreenda as necessidades de reparação histórica à maioria negra socialmente invisibilizada.

São ocupações de espaços de poder que recriem decisões estruturantes em relação ao coletivo, ao transinsdividual, à intergeracionalidade social e institucional, fundadas e direcionadas, a partir de uma consciência negra sobre a sua posicionalidade no poder, depois de estabelecida sua relação de encontro com o mundo, pois o/a negro / a tem sido identificado, frequentemente, pelo esgarçamento existencial.

Foi pela negação de humanidade ao negro que o Ocidente se tornou, fragmentariamente, monumental. Parece que se estar por cair, que se está por irromper nova ordem mundial. Nada disso. São atualizações exploratórias que contam com o despedaçamento do corpo negro, dardejado pela libido estonteante do capitalismo de vigilância.

Almejam-se ocupações de espaços de poder que não representem apenas uma figuração estética da negritude (cabelos, vestimenta, religiosidade etc.). E que também não sirvam como falsa reparação histórica da própria institucionalidade, que tem, como viés histórico-racial, o hábito de assimilar o negro como uma espécie de suvenir da diáspora africana: o negro como objeto de decoração na prateleira branca.

Essa irrupção contra a antinegritude, e consequente destruição do pacto narcisístico da branquitude, não pode contar com uma hermenêutica constitucional universalizante, própria de um certo conservadorismo eurocêntrico, e até norte-americano, que sempre se valeu da igualdade formal. Hermenêutica constitucional que consta na programação de estudos e editais de acesso à carreira de promotor de justiça. Para se tornar um promotor/a de justiça, deve-se submeter a energia mental e criativa a um poder-saber massificante, que nega a própria historicidade brasileira, por meio da obrigatoriedade de o candidato/a ao cargo ter de aprender, excessivamente, conceitos abstratos.

Assim, como há 10 anos, sociologia e filosofia não integravam os editais de concurso público de carreiras estatais (promotor, juiz e defensor público), e passaram a integrá-los ${ }^{50}$, já é tempo de se exigir, nos editais de concurso para promotor de justiça, matérias como decolonialidade, epistemologias do sul e amefricanidade, que permitam uma nova reflexão prática da atividade do Ministério Público para a realidade social brasileira, recente e incompletamente liberta da escravidão, e que, ainda, continua a tratar, na prática social e acadêmica, o negro como cobaia sociológica. ${ }^{51}$ Cento e trinta e dois anos de alforria formal é um pequeno tempo quando comparado com a "atemporalidade da opressão no mundo".

Há na recusa à incorporação dessas matérias algo que diz muito sobre o narcisismo da branquitude.

Consoante Maria Aparecida, a pacto narcisístico da branquitude - perspectiva que também pode ser adotada para compreender as relações dentro da instituição do Ministério Público — se refere a esse estado de manutenção histórica de privilégios sociais da branquitude, que, deliberadamente e com códigos de silêncios entre si, se recusa a discutir o legado da escravidão para o branco, o lugar do branco na apropriação de quatro séculos de trabalho do grupo negro, que lhes renderam benefícios econômicos, sociais e simbólicos, a ponto de reduzir a problemática racial como uma questão unicamente pertencente ao negro. Esse acordo

\footnotetext{
$50 \quad$ Neste sentido, os últimos editais de concurso público para ingresso na carreira de defensor público da Bahia e para promotor de justiça de Minas Gerais.

51 MOURA, Clóvis. Sociologia do negro brasileiro. 2ª ed. São Paulo: Perspectiva, 2019. p. 139.
} 
tácito na branquitude permite que brancos, da elite ou não, deixem de prestar contas sobre a continuidade exploratória sobre o negro. ${ }^{52}$

É o que Alberto Guerreiro Ramos, na década de 1950, ao documentar sua sociologia militante, já havia denunciado como a "patologia social do branco brasileiro", em que o branco estava preocupadíssimo em ressaltar suas características de brancura e, por assim dizer, de sua superioridade racial e social, significativa de diversos privilégios. Só que, como o referido sociólogo advertiu à época, essa ideologia da brancura "embaraça o processo de maturidade psicológica do brasileiro" para que se realize um contexto social e racial mais sincero. ${ }^{53}$

Nesse cenário, deve-se, com a noção de amefricanidade de Lélia Gonzalez, amefricanizar a percepção sobre o Ministério Público brasileiro, para fazer dele uma instituição responsável pela concretização democrática de um país formado, significativamente, por descendentes de africanos e ameríndios, situação que se dá, também, em outros países da América Latina (Bolívia, Peru, Cuba). ${ }^{54}$ Amefricanizar no sentido de fazê-lo entender que sua luta política e de poder estatal é contra qualquer forma de intenção e ação neocolonialista que se desenvolva na sociedade brasileira, de fazer abolir o racismo à brasileira. Amefricanizar-se, enquanto categoria político-cultural, também significa não se submeter ao espoliante neoliberalismo que se apossou do mundo.

Para amefricanizar o Ministério Público, não se precisará de uma nova constituinte, de uma nova Constituição, e sim de uma cultura e hermenêutica constitucional que reconheçam a necessidade de interpretar normas jurídicas fundamentais, a partir do que a sociedade brasileira efetivamente é: antinegra e narcisisticamente branca. Thula Pires oferece essa nova possibilidade hermenêutica, quando também se valendo da categoria político-cultural da amefricaniade, alerta para a necessidade de desenvolvimento de um constitucionalismo ladino-amefricano, que considere a práxis afrocentrada e o giro decolonial, estimulados pelo protagonismo negro de resistência que, apesar de silenciado constitucionalmente, oferece uma relação de saber não hierarquizada, respeitando-se cosmovisões amefricanas e ameríndias radicadas na América Latina. ${ }^{55}$

Avançando-se numa proposta de concepção de hermenêutica constitucional, que denomina de Hermenêutica Negra, Adilson José Moreira convida a uma perspectiva antissubordinatória, como forma de interpretação do princípio da igualdade. Não é natural que um Princípio de Justiça, teoricamente forte e de previsão constitucional, continue a ser praticado socialmente, de maneira que grupos sociais e raciais marginalizados continuem ininterruptamente nessa condição degradante. Por essa visão insubmissa quanto à intepretação constitucional do Princípio da Igualdade, este funcionaria como forma de articulação entre diferença e igualdade, com a tônica de se pensar em ações estatais que realizem, de forma inclusiva, direitos fundamentais básicos de uma comunidade negra, sistematicamente deteriorada no seu existir por uma opressão exercida, como regra, por pessoas não negras. ${ }^{56}$

O processo de Amefricanização do Ministério Público não se dará como decurso natural da história do Ministério Público, que continua a seguir, conforme sublinhado em tópicos anteriores, a socialmente excludente tradição de ideias liberais no campo das ações institucionais. Não será uma decorrência natural e

52 BENTO, Maria Aparecida Silva. Branqueamento e Branquitude no Brasil. In: BENTO, Maria Aparecida Silva. CARONE, Iray (Orgs). Psicologia Social do Racismo. Estudos sobre branquitude e branqueamento no Brasil. Edição Kindle. Rio de Janeiro: Vozes, 2016.p. 338-972. Nesse mesmo sentido: DE OLIVEIRA PIRES, Thula Rafaela. Criminologia crítica e pacto narcísico: por uma crítica criminológica apreensivel em pretuguês. Revista brasileira de ciências criminais, n. ${ }^{\circ}$ 135, p. 541-562, 2017; FAUSTINO, Deivson Mendes. Franz Fanon, a branquitude e a racialização: aportes introdutórios a uma agenda de pesquisas. In: MÜLLER, Tânia MP; CARDOSO, Lourenço. Branquitude: estudos sobre a identidade branca no Brasil. Edição Kindle. Curitiba: Appris, 2017. p. 2.146-2416.

53 RAMOS, Alberto Guerreiro. Introdução crítica à sociologia brasileira. Rio de Janeiro: Editora UFRJ, 1995. p. 231.

54 GONZALEZ, Lélia. A categoria politica-cultural de amefricanidade. In: Tempo Brasileiro. N. 92/93 (jan./jun). Rio de Janeiro: 1988. p. 69-82.

55 PIRES, Thula. Por um constitucionalismo ladio-amefricano. In: BERNARDINO-COSTA, Joaze; MALDONADO-TORRES, Nelson; GROSFOGUEL, Ramón (Orgs). Decolonialidade e pensamento afrodiaspórico. Edição Kindle. Belo Horizonte, Autêntica, 2018. p. 5.9486229.

56 MOREIRA, Adilson. Pensar como um negro. Ensaio de Hermenêutica Jurídica. São Paulo: Editora Contracorrente, 2019. p. 266-268. 
exclusiva do acesso ao cargo por pessoas negras. Mesmo com a implementação das cotas, o quantitativo de negros e negras no Ministério Público continua, em termos de poder decisivo, pequeniníssimo.

Ocorrerá, como primeiro passo, com a publicização do perfil racial de cada Ministério Público brasileiro, seguido de uma ampla e séria discussão sobre o acesso ao poder institucional, a partir da intersecção entre gênero e raça, já que as mulheres, e, principalmente, mulheres negras, continuam sendo as principais exclú́das do campo de poder. Essa discussão deverá ser conduzida também no Conselho Nacional do Ministério Público. Devem ser criados grupos temáticos sobre a questão racial, envolvendo promotores e promotoras negros/as, fortalecendo o despertar e cultivar de uma consciência negra. Devem ser promovidos diálogos com promotores não negros para que entendam sobre seu lugar de herdeiros de privilégios sociais e institucionais, a fim de que possam se aliar a essa luta contra a antinegritude estrutural.

Novas promotorias de combate à discriminação racial devem ser criadas e espalhadas por todo o Estado da Bahia e nos outros Ministério Públicos brasileiros, como forma de implementar o Estatuto da Igualdade Racial (Lei n. ${ }^{\circ}$ 12.288/10). A partir dessas linhas, o despertar e perenizar de uma consciência negra se tornarão objeto concreto de um sério planejamento estratégico do Ministério Público, preocupado em superar a domínio racial estrutural exercido por não negros, em regra brancos, sobre a diminuta e silenciosa negritude que compõe a instituição.

Os negros e negras institucionalizados no Ministério Público devem buscar conhecer o conceito de quilombismo, desenvolvido por Abdias Nascimento, para que entendam a importância de se reconhecerem enquanto grupo minoritário na instituição e ainda sujeito a exclusões e discursos discriminatórios no trato cotidiano com seus pares. Fazê-los entender que é necessária uma aglutinação afetiva, inteligente e estratégica sobre a questão racial. Reconhecer-se como dentro de uma negritude maior, que transborde o aspecto institucional, para que não caiam na confortável sonolência mental da estabilidade pública. A luta é coletiva, dentro e fora da instituição. ${ }^{57}$

A luta é psicológica, dentro do ser e para ser negro, como forma de estabilizar sua saúde mental, a partir da internalização do conhecimento profundo do que é a negritude e seus movimentos dinâmicos de conquistas e retrocessos. Aquilombar-se para acreditar na idoneidade mental do negro, para se reinventar nos traços de sua própria história, contadas pelos seus historiadores e sociólogos que, com muita militância, conseguiram furar cinturões acadêmicos de proteção da inteligência supremacista branca.

Aquilombar-se para resistir à dominação racial, que, mesmo numa instituição de semblante democrático como o Ministério Público, obstaculiza a subjetivação maior, a conquista de poder, da intelectualidade negra. Aquilombar-se para produzir comunhões de vida em torno de um ideal: destrinchar a antinegritude e não condescender com poucas migalhas institucionais e financeiras distribuídas pelos dominantes raciais. As estratégias de amefricanização são, também, estilos de aquilombamento. Amefricanizar-se e aquilombar-se formam um só movimento para a posse coletiva de uma nova consciência negra, que a contemporaneidade exige, sem subalternizar-se e esconder-se nas roupas sujas e antigas do vetusto pensamento eurocêntrico.

Aliás, “a Europa é indefensável”, isso foi dito inesquecivelmente por Aimé Césaire. ${ }^{58}$

$\mathrm{E}$ antes que se pense que se amefricanizar e aquilombar-se sejam apenas verbos poéticos, inúteis à prática institucional do Ministério Público, deve-se observar que a outra opção que lhe restaria, isto é, negar tais perspectivas de giro decolonial, seria compactuar com o estado atual de segregação racial disfarçada pelo discurso de democracia racial, que conquistou a sociedade brasileira. Ter-se-ia, na prática social, um Ministério Público cúmplice com práticas racistas, assim como foi o Ministério Público da África do Sul com o regime de apartheid nas décadas de 1948 a 1978, perseguindo — a mando do Executivo do qual fazia parte — negros e negras acusados (as) de crimes políticos. ${ }^{59}$

57 NASCIMENTO, Abdias. O quilombismo: documentos de uma militância pan-africanista. $3^{\text {a }}$ ed. Rio de Janeiro, Ipeafro, 2019 . p. 296 a 301.

58 CÉSAIRE, Aimé. Discurso sobre o colonialismo. Florianópolis: Letras Contemporâneas, 2017. p. 15.

59 MULLER, Felipe da Silva. National Prosecuting Authority:o Ministério Público da África do Sul no periodo pós-apartheid. Boletim Científico ESMPU, Brasília, a. 17 - n. 51, p. 351-368 - jan./jun. 2018. 


\section{Considerações finais}

Há um longo caminho a ser percorrido pelo Ministério Público, se, de fato pretende, enquanto instituição constitucional, desviar-se da saga histórica que o sempre fez composto por elites, intelectualizadas ou não, que não trouxeram o debate racial para dentro da instituição. O ponto de partida do Ministério Público precisa ser repensado: ainda crê que há democracia racial no país.

Ao abrir o discurso racial dentro da instituição, com apostas em perguntas sólidas e constrangedoras sobre a perpetuação do poder branco na liderança institucional, é possível começar a falar sobre a tal vocação socialmente transformadora do Ministério Público. Sem isso, é uma instituição, como nos diz a refinada sabedoria popular, que representa o mais do mesmo, a perene segregação racial à brasileira, que é disfarçada enquanto estratégia antinegra, mas extremamente real e sentida pelos corpos negros que, quando não encarcerados, agonizam seu estado de liberdade, reféns do impacto desnudante dos olhares sociais que os representam como potenciais criminosos.

Acordar. Abrir o discurso. Enegrecer-se. Transformar-se. Aquilombar-se. Amefricanizar-se. Imperativos do tempo presente para um Ministério Público brasileiro, que esteja realmente preocupado com a renovação institucional e social.

\section{Referências}

ALMEIDA, Silvio. Racismo estrutural. São Paulo: Polén, 2019.

AKOTIRENE, Carla. Interseccionalidade. São Paulo: Polén, 2019.

ARANTES, Rogério Bastos. Direito e politica: o Ministério Público e a defesa dos direitos coletivos. Revista brasileira de ciências sociais, v. 14, n. 39, 1999. p. 83-102.

BARCELLOS, Ana Paula Gonçalves Pereira de. Constituição e pluralismo jurídico: a posição particular do Brasil no contexto latino-americano. Revista Brasileira de Políticas Públicas, v. 9, n. 2, p. 170-183, 2019.

BARROS, Bruno Mello Correa; ALBRECHT, Rita Mara. A discriminação racial no Brasil e a ascensão do povo negro: um olhar a partir dos princípios constitucionais na luta pela cidadania inclusiva. Revista Brasileira de Políticas Públicas, v. 9, n. 1, p. 14-33, 2019.

BENTO, Maria Aparecida Silva. Branqueamento e Branquitude no Brasil. In: BENTO, Maria Aparecida Silva. CARONE, Iray (Orgs). Psicologia Social do Racismo. Estudos sobre branquitude e branqueamento no Brasil. Edição Kindle. Rio de Janeiro: Vozes, 2016.p. 338-972.

CÉSAIRE, Aimé. Discurso sobre o colonialismo. Florianópolis: Letras Contemporâneas, 2017. p. 15.

HOOKS, Bell . Ensinando a transgredir: a educação como prática da liberdade. Trad. Marcelo Brandão Cipolla. $2^{\text {a }}$ ed. São Paulo: Martins Fontes, 2017.

BINENBOJM, Gustavo. Uma teoria do direito administrativo: direitos fundamentais, democracia e constitucionalização. Rio de Janeiro: Renovar, 2014.

BRITTO, Carlos Ayres. Teoria da constituição. Rio de Janeiro: Forense, 2006.

BUCK-MORSS, Susan. Hegel e Haiti. Novos estud. - CEBRAP, São Paulo, n. 90, p. 131-171, jul. 2011. Disponível em <http://www.scielo.br/scielo.php?script=sci_arttext\&pid=S0101- 3002011000200010\&lng =pt\&nrm=iso $>$. Acesso em: 15 mai. 2020. https://doi.org/10.1590/S0101-33002011000200010. 
CARDOSO, Lourenço. A branquitude acrítica revisitada e as críticas. In: MÜLLER, Tânia MP; CARDOSO, Lourenço. Branquitude: estudos sobre a identidade branca no Brasil. Edição Kindle. Curitiba: Appris ,2017.

COLLINS, Patricia Hill. Aprendendo com a outsider within: a significaşão sociológica do pensamento feminista negro. Sociedade e Estado, v. 31, n. 1, p. 99-127, 2016.

DA SILVA, Iraneide Soares. A Trajetória dos Estudos sobre Relações Raciais no Brasil. Padê: Estudos em filosofia, raça, gênero e direitos humanos, v. 1, n. 1, 2007

DAVIS, Angela Y. Mulheres, raça e classe. Trad. Heci Regina Candiani. 1a ed. São Paulo: Boitempo, 2016.

DE OLIVEIRA PIRES, Thula Rafaela. Criminologia crítica e pacto narcísico: por uma crítica criminológica apreensivel em pretuguês. Revista brasileira de ciências criminais, n. 135, p. 541-562, 2017;

Por um constitucionalismo ladio-amefricano. In: BERNARDINO-COSTA, Joaze; MAL-

DONADO-TORRES, Nelson; GROSFOGUEL, Ramón (Orgs). Decolonialidade e pensamento afrodiaspórico. Edição Kindle. Belo Horizonte, Autêntica, 2018. p. 5.948- 6229

DE SOUZA ASSUMPÇÃO, Vinícius. A gestão do corpo negro no Brasil: da democracia racial ao genocídio. Revista de Criminologias e Políticas Criminais, v. 3, n. 1, p. 20-41, 2017

DUARTE, Evandro Charles Piza; QUEIROZ, Marcos Vinícius Lustosa. A Revolução Haitiana e o Atlântico Negro: o Constitucionalismo em face do Lado Oculto da Modernidade. Revista Direito, Estado e Sociedade, n. 49, p. 10-42. jul/dez.2016.

FAUSTINO, Deivson Mendes. Franz Fanon, a branquitude e a racialização: aportes introdutórios a uma agenda de pesquisas. In: MÜLLER, Tânia MP; CARDOSO, Lourenço. Branquitude: estudos sobre a identidade branca no Brasil. Edição Kindle. Curitiba: Appris ,2017.

FANON, Frantz. Pele negra, máscaras brancas. Salvador: Edufba, EDUFBA, 2008. p.107.

FERNANDES, Florestan. O negro no mundo dos brancos. Global Editora e Distribuidora Ltda, 2015.

FERREIRA, Ana Gabriela Souza. As disfunções da linguagem na proteção à dignidade de gênero - a inexistência do bumano feminino no processo penal. Disponível em https://www.academia.edu/37482217/AS_DIS_ FUN $\%$ C3 $\% 87 \%$ C3\% $\% 5$ ES_DA_LINGUAGEM_NA_PROTE $\%$ C3\%87\%C3\%83O_\%C3\%80_DIGNIDADE_DE_G\%C3\%8ANERO_A_INEXIST\%C3\%8ANCIA_DO_HUMANO_FEMININO_NO_ PROCESSO_PENAL. Acesso em: 10 ago. 2020

FLAUZINA, Ana Luiza Pinheiro. As fronteiras raciais do genocídio. University of Brasília Law Journal (Direito. UnB), v. 1, n. 1, p. 705, 2016.

KERCHE, Fábio. Virtude e Limites: Autonomia e Atribuições do Ministério Público no Brasil. São Paulo: Edusp, 2009.

GONZALEZ, Lélia. O golpe de 64, o novo modelo econômico e a população negra. In: GONZALEZ, Lélia; HASENBALG, Carlos Alfredo. Lugar de negro. Rio de Janeiro: Marco Zero, 1982. p. 11-18.

A categoria politica-cultural de amefricanidade. In: Tempo Brasileiro. N. 92/93 (jan./jun). Rio de Janeiro: Tempo Brasileiro, 1988 p. 69-82

GOULART, Marcelo Pedroso. Elementos para uma teoria geral do Ministério Público. Belo Horizonte: Arraes Editores, 2013

LIMA, Polastri Marcellus. Ministério Público e Persecução Penal. 5a ed. Salvador: Juspodivm, 2016.

LOSURDO, Domenico. Contra-história do liberalismo. Trad. Giovanni Semeraro. São Paulo: Ideias e Letras, 2020. 
MAGALHÃES, José Luiz Quadro; SANTOS, Braulio Magalhães. Notas para um debate principiológico sobre participação à luz de uma teoria democrática. Rev. Bras. de Políticas Públicas, Brasília, v. 1, n. 2, p. 1-30, jul./dez. 2011

MAGNAVITA, Andréa Costa. Invisibilidade pública: a história quilombola. Padê: Estudos em filosofia, raça, gênero e direitos humanos, v. 1, n. 1, p. 17-33, jan./jun. 2010.

MAZZILLI, Hugo Nigro. Introdução ao ministério público. São Paulo: Saraiva, 2005.

MBEMBE, Achille. Crítica da razão negra. Trad. Sebastião Nascimento. São Paulo: N-1 Edições, 2018

MEMMI, Albert. Retrato do colonizado: precedido do retrato do colonizador. Trad. Marcelo Jacques de Moraes. Rio de Janeiro: Civilização Brasileira, 2007.

MINHOTO, Antonio Celso Baeta. Refletindo sobre liberdade e igualdade dos negros: as ideias de Rawls e Walzer para um debate da ação afirmativa. Revista Brasileira de Políticas Públicas, v. 3, n. 1, p.105-117, 2013.

MOREIRA, Rafael Bueno da Rosa; COSTA, Marli Marlene Morais. As mulheres no contexto da sociedade de classes e sua participação política no processo legislativo e executivo do Brasil: das restrições e desafios. Revista Brasileira de Políticas Públicas, v. 9, n. 1, p. 34-54, 2019.

MULLER, Felipe da Silva. National Prosecuting Authority:o Ministério Público da Africa do Sul no período pós-apartheid .Boletim Científico ESMPU, Brasília, a. 17 - n. 51, p. 351-368 - jan./jun. 2018.

MUNANGA, Kabengele. Negritude-usos e sentidos. $4^{a}$ ed. Belo Horizonte: Autêntica, 2019.

Rediscutindo a mestiçagem no Brasil: identidade nacional versus identidade negra. 5.ed. Belo Horizonte:

Autêntica, 2019. p

MOREIRA, Adilson. Pensar como um negro. Ensaio de Hermenêutica Jurídica. São Paulo: Editora Contracorrente, 2019.

MOURA, Clóvis. Sociologia do negro brasileiro. $2^{\text {a }}$ ed. São Paulo: Perspectiva, 2019.

NASCIMENTO, Abdias. O genocídio do negro brasileiro: processo de um racismo mascarado. $3^{a}$ ed. São Paulo: Perspectiva, 2016.

. O quilombismo: documentos de uma militância pan-africanista. $3^{\text {a }} \mathrm{ed}$. Rio de Janeiro, Ipeafro, 2019.

RAMOS, Alberto Guerreiro. Introducão crítica à sociologia brasileira. Rio de Janeiro: Editora UFRJ, 1995.

SARMENTO, Daniel. Livres e iguais: estudos de direito constitucional. Rio de Janeiro: Editora Lumen Juris, 2006.

SILVA, José Afonso da. Comentário contextual à Constituição. 2aed. São Paulo: Malheiros, 2006

SILVA, Jonata Wiliam Sousa da. Sistema de Justiça Criminal e a questão racial: caminhos para a ocupação de pessoas negras nos espaços de poder. In: Enegrecendo o Direito. Questões raciais no Brasil. Coord. Julio Rocha. p. 121133. Salvador: Mente Aberta, 2020.

STRECK, Lenio Luiz; MORAIS, José Luís Bolzan de. Ciência política e teoria do estado. Porto Alegre: Livraria do Advogado, 2019. p. 134-136.

TELLO, Diana Carolina Valencia. As instituições e a via da dependência histórica. Rev. Bras. de Políticas Públicas, Brasília, v. 1, n. 1, p. 35-64, jan./jun. 2011.

TOURINHO FILHO, Fernando da Costa. Manual de Processo Penal. São Paulo: Saraiva, 2012.

VARGAS, João H. Costa. Por uma Mudança de Paradigma: Antinegritude e Antagonismo Estrutural . Revista de Ciências Sociais. Fortaleza, v.48, n. 2, p.83-105, jul./dez., 2017.

Racismo não dá conta: antinegritude, a dinâmica ontológica e social definidora da modernidade. Revista Em

Pauta: teoria social e realidade contemporânea, v. 18, n. 45, p. 16-25, 2020. 
VAZ, Livia Maria Santana e Sant'Anna. Ações Afirmativas: aplicação às políticas de saúde para a população negra. Dissertação de mestrado (UFBA-2016.222p.). Disponível em https://repositorio.ufba.br/ri/handle/ ri/9304. Acesso em: 10. ago. 2020.

Eu, mulher negra, não sou um sujeito universal!. Disponível em https://www.jota.info/opiniao-eanalise/artigos/eu-mulher-negra-nao-sou-sujeito- universal-12082020. Acesso em: 12. agos. 2018

WERNECK, Jurema. Nossos passos vêm de longe! Movimentos de mulheres negras e estratégias políticas contra o sexismo e o racismo in: Mulheres negras: um olhar sobre as lutas sociais e as políticas públicas no Brasil. Org. Jurema Werneck. Rio de Janeiro: Criola, 2010.

ZANETI JR, Hermes. O Ministério Público e o novo processo civil. Salvador: JusPodivm, 2018.

ZUBERI, Tukufu. Teoria crítica da raça e da sociedade nos Estados Unidos. Cadernos do CEAS: Revista crítica de humanidades, n. 238, p. 464-487, 2016. 
Para publicar na revista Brasileira de Políticas Públicas, acesse o endereço eletrônico www.rbpp.uniceub.br

Observe as normas de publicação, para facilitar e agilizar o trabalho de edição. 